\title{
Assessment of Environmental Pollution and its Impact on Water Resources, Soils and Crops in the Area Adjacent Bahr El-Bakr Drain, East-Delta, Egypt Abdel-Hameed M. El-Aassar ${ }^{1}$, Sherine M. shehata ${ }^{2}$, Amal M. Omer ${ }^{3}$, Reham K. I. Badawy ${ }^{4}$
}

\begin{abstract}
Assessment of the environmental impact of the polluted water was studied along Bahr El-Bakr drain. Different samples of water, soil and the edible parts of vegetables, cereals and clover were collected from the study area. Chemical and/or microbiological analyses of these samples were achieved to examine water, soil and plant contamination. Chemical analysis of the collected water samples, that represented all irrigation water resources, showed that they range from fresh to brackish. For soluble heavy metals, there is no any inorganic pollutant in the collected water samples except one sample with high aluminum and iron concentrations, while using digestion method, high concentrations of most metals for all collected samples were recorded. On the other hand, high concentrations of organic pollutants included both TOC and COD were detected in most water samples.
\end{abstract}

Microbiological investigation of the water samples revealed their highly contamination with fecal coliforms and pathogenic bacteria. All soil samples of the study area showed remarkable pollution with higher microbial contamination compared to that of irrigation water of the same place.The summary statistics results indicated that the most important heavy metals with regards to potential hazards in studied soils are $\mathrm{Pb}$ and $\mathrm{Cd}$. Average contamination factor values for heavy metals have the order $\mathrm{Cd}>\mathrm{Co}>\mathrm{Ni}>\mathrm{Cr}>\mathrm{Cu}>\mathrm{Pb}>\mathrm{Zn}>\mathrm{Fe}$, suggesting that soil samples were extremely enriched with $\mathrm{Cd}$, while $\mathrm{Pb}$ exhibit significant enrichment. Geoaccumulation index showed that the soils of Bahr El-Bakr were uncontaminated with $\mathrm{Fe}, \mathrm{Zn}, \mathrm{Cu}, \mathrm{Ni}, \mathrm{Co}$ and $\mathrm{Cr}$ and moderately contaminated with $\mathrm{Pb}$ but $\mathrm{Cd}$ followed strongly/ extremely contaminated index.

It was also observed an elevation in nitrate contents in the edible parts of the collected leafy vegetables. Heavy metal concentrations in leaves, cereal, fruits tubers of edible parts of plants and shoots of clover plants decreased in the order; $\mathrm{Fe}>\mathrm{Al}>\mathrm{Zn}>\mathrm{Cu}>\mathrm{Mn}>\mathrm{B}>\mathrm{Ni}>\mathrm{Cr}>\mathrm{Pb}$ $>\mathrm{Ba}>\mathrm{V}>\mathrm{Mo}>\mathrm{Co}>\mathrm{Cd}$, with increase of toxic metals such as $\mathrm{Al}, \mathrm{Cr}, \mathrm{Pb}, \mathrm{Ni}$ and $\mathrm{Cd}$ concentrations that were higher than the permissible limits. These results indicated that long term irrigation with waste water from Bahr El-Bakr drain had a negative impact on both chemical and microbiological quality of soil and plants in this region.

Keywords:Bahr El-Bakr, irrigation water, microbiological contamination, heavy metal.

\section{INTRODUCTION}

In the arid areas where there is an increasing need for water and due to the shortage in water resources, these resulted in the emergence of wastewater application in agriculture to reduce the demand of freshwater resources. Approximately 70\% of treated wastewater is used for agriculture (Cytryn, 2010) and may have detrimental environmental and health effects. Production of plants irrigated with treated wastewater was increased compared to plants irrigated with natural water.This may be due to the presence of plant nutrients (mainly nitrogen and phosphorus) in the treated wastewater, but the risk due to the presence of some pathogens and precautions about the reverse effect of treated wastewater used in the irrigation of edible crops are still under consideration (Mandi and Abissy, 2000, Munir and Mohammad, 2004, Lopez et al., 2007). Thus, there is a great need to evaluate the water from microbiological aspect before using in irrigation process.

Bahr El-Bakr is considered as one of the most polluted drain in Egypt (Abdel-Shafy and Aly, 2002). It receives and carries the greatest part of waste water into Lake Manzalla through a very densely populated area of the Eastern Delta passing through Qalubyia, Sharki, Ismailia and Port Said Governorates. The drain is 106 $\mathrm{Km}$ long and has two main branches (73.2 Km Qalubyia drain and $66 \mathrm{Km}$ Bilbies drain). Effluents discharged to Bahr El-Bakr drain are nearly about $6548741 \mathrm{~m}^{3} /$ day of wastewater (Nile Basin water Quality Monitoring Baseline Report 2005). Heavy metals are important environmental pollutants, particularly in areas with high anthropogenic pressure their presence in the atmosphere, soil and water; even in traces, can cause serious problems to all organisms.

Heavy metal accumulated in soils is of concern in agriculture production due to the adverse effects on food quality (Ma et al., 1994). Crop plants especially vegetables growing on heavy metal contaminated medium can accumulate high concentrations of trace elements and heavy metals which cause serious health risk to consumers (Islam et al., 2007).

${ }^{1}$ Hydro-geochemistry, Desert Research Center, Cairo, Egypt

${ }^{2}$ Soil Chemistry and Physics Department,Desert Research Center, Cairo, Egypt

${ }^{3}$ Soil Fertility and Microbiology Department, Desert Research Center, Cairo, Egypt,

${ }^{4}$ Environmental Pollution Unit, Plant Ecology and Range Management Department,

Desert Research Centre, Cairo, Egypt.

Corresponding author reee_2005@yahoo.com

Received February 21, 2018, Accepted March 27, 2018 
Increased exposure to nitrogen-containing compounds such as nitrate/ nitrite, due to increased usage of nitrogen fertilizers and additives containing nitrite in processed food products is becoming an important public health issue (Chan, 2011).Although nitrate is apparently non-toxic below maximum residue levels, it may be endogenously transformed to nitrite that can react with amines and amides to produce $\mathrm{N}$ nitroso compounds (Correia, et al., 2010). These have been related to an increases risk of gastric cancer (TaeRang, et al., 2011). Nitrate can also have a tetratogenic effect and with the formation of methemoglobin the oxygen transmission to tissues is disrupted (Santamaria, 2006). Lethal dose of the incoming nitrate from food is 330 per Kg of body weight (Walker, 1990).

While the most pathogenic microorganisms responsible for waterborne diseases were originated from a faecal-oral transmission route. Therefore, fecal coli bacteria (FCB) are frequently investigated in determining the hygienic quality of water as they present in human and animal feces. Within the FCB group, E.coli bacteria are the most species of fecal coli bacteria and commonly used as indicators of fecal contamination in the natural environment of water, soils and plants (Edberg et al. 2000; Lee et al. 2006; Haller et al. 2009; Palese et al. 2009). Furthermore, species of the genus Streptococcus cause pneumonia, ear infection and meningitis. Like fecal coli bacteria, fecal streptococci are applied as indicators of water pollution and have been used for many years to determine the quality and safety of water for irrigation and human consumption (WHO, 1989, Ashraf, 2014).

The present work was undertaken to assess the longterm effect of irrigation with Bahr El-Bakr drain water on different chemical pollutants and microbial contamination in water, soil and the edible parts of some cultivated crops through comparing their concentrations with the permissible limits.

\section{Site description and field work:}

\section{MATERIALS AND METHODS}

The study area is located in the vicinity of Bahr ElBakr drain, East-delta, Egypt, figure (1).

Bahr El-Bakr bank is a source of pollution in Egypt, it was established in around hundred years ago, which dedicated to exchange of agricultural only, but in the early seventies of the last century the government decided to convert it to receive the sewage of the population of Greater Cairo. It is represented the most dangerous sources of pollution to the magnitude of industrial wastes, agricultural and sewage untreated.

A field trip was achieved during spring and summer 2017, through which a survey of all available irrigation water sources was carried out and both surface and groundwater samples were collected, locations were recorded using (GPS), as shown in figure (2). Also, in situ measurements of both $\mathrm{pH}$ and the electrical conductivity (EC) were carried out.

Water and soil samples were collected for chemical analysis. For microbiological analyses, the collected water and soil samples were brought in an ice-container during transport and delivered to the analytical laboratory. Also, the edible portion of thirteen types of crops in addition to one fodder crop as clover was collected from the study area with three replicates. Details of different plants sample during the study were recorded in Table (1).

\section{Experimental analyses}

\section{1- Water analysis}

Chemical analysis of water samples: The total 10 water samples were analyzed at Water Analysis Unit of the Central Laboratory of Desert Research Center (DRC, Cairo, Egypt). The chemical analyses of the collected water samples included the determination of $\mathrm{EC}$, total dissolved salts (TDS), $\mathrm{pH}$, the determination of concentrations of major soluble cations $\left(\mathrm{Na}^{+}, \mathrm{K}^{+}\right.$, $\left.\mathrm{Mg}^{2+}, \mathrm{Ca}^{2+}\right)$ and anions $\left(\mathrm{Cl}^{-}, \mathrm{SO}_{4}{ }^{2-}, \mathrm{CO}_{3}{ }^{2-}, \mathrm{HCO}_{3}{ }^{-}\right)$by ion chromatography (ICS-1100, Dionex, Sunnyvale, $\mathrm{CA}, \mathrm{USA})$. Also, the trace elements ( $\mathrm{Al}, \mathrm{B}, \mathrm{Cd}, \mathrm{Co}, \mathrm{Cr}$, $\mathrm{Cu}, \mathrm{Fe}, \mathrm{Mn}, \mathrm{Mo}, \mathrm{Ni}, \mathrm{Pb}, \mathrm{Ti}, \mathrm{Sr}, \mathrm{P}, \mathrm{V}$, and $\mathrm{Zn}$ ) concentrations of the water samples were determined using Inductively Coupled Aragon Plasma (ICAP, Thermo 6500). Another analysis for the heavy metals were done by digestion method to determine total concentration of metal content which combine with organic materials, the digestion was performed by taking $5 \mathrm{~mL}$ of water sample, concentrated $\mathrm{HNO}_{3}$ (7.5 $\mathrm{mL}$ ) and $2 \mathrm{ml} \mathrm{H}_{2} \mathrm{O}_{2}$ were added in teflon closed vessels of microwave digestion. After that the samples were filtrated into a $25 \mathrm{ml}$ volumetric flask using Whatman No. 44 filter paper and made up to the mark with distilled water(Bhuyan, et al., 2017).Also, the concentrations of nitrate, TOC, OM and COD were measured according to (ASTM, 2002).

Microbiological Examination of water: The total viable bacterial counts (TVBCs) as well as indicators of fecal contamination including (total Coliform, fecal Coliform and fecal Streptococci) were investigated. TVBCs for water and soil samples were determined using pour plate method on nutrient agar medium, three replicates were incubated at $37^{\circ} \mathrm{C}$ for 24 hours (ElShenawy, 2005). The number of total and fecal coliforms was determined by the most probable number (MPN) method using MacConkeybroth medium. Tubes of MacConkey medium were incubated at $37^{\circ} \mathrm{C}$ for $48 \mathrm{hr}$ for total coliforms and at $44^{\circ} \mathrm{C}$ for $24 \mathrm{hr}$ for fecal 


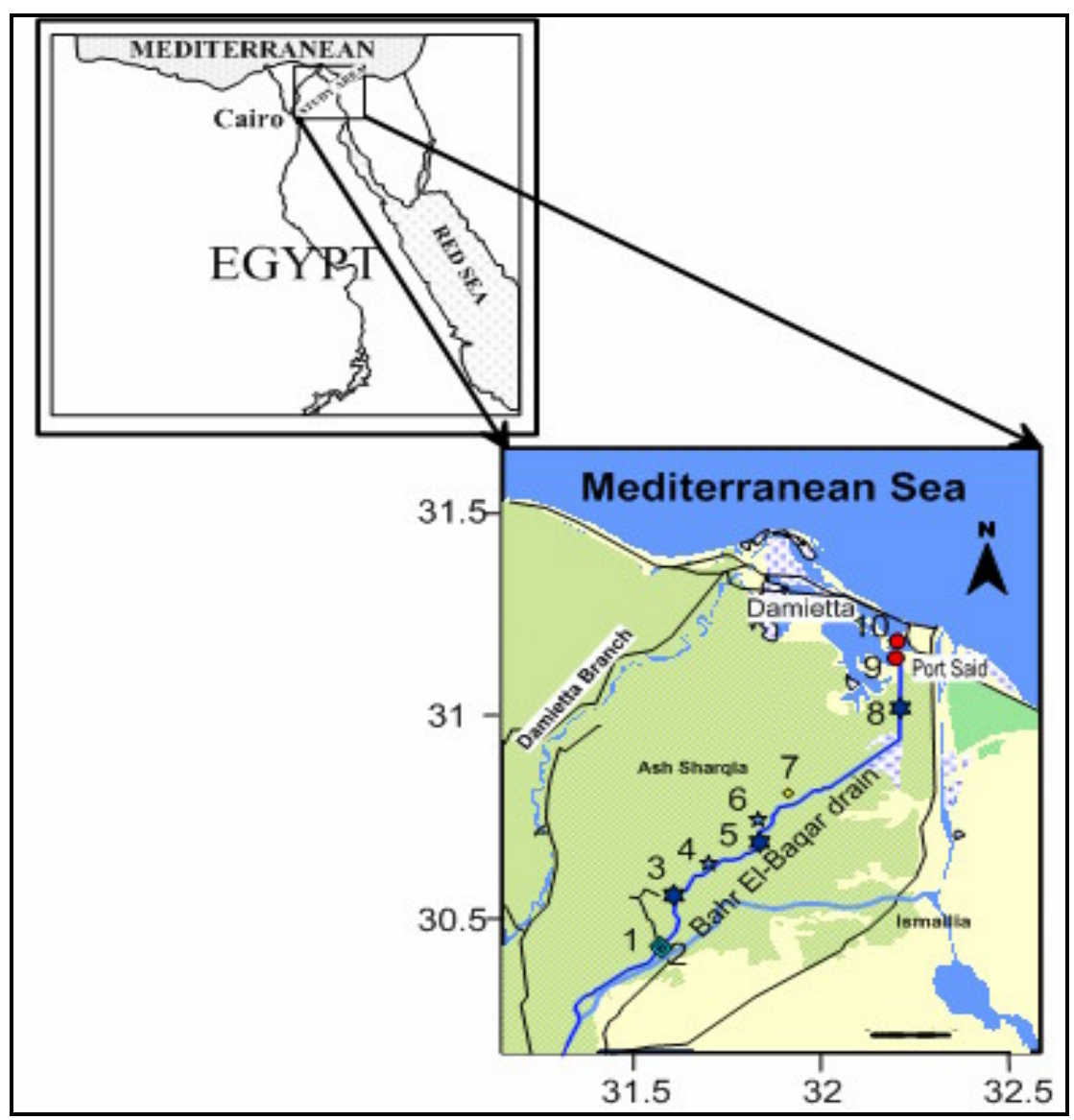

Figure 1. Locations map and sampling sites
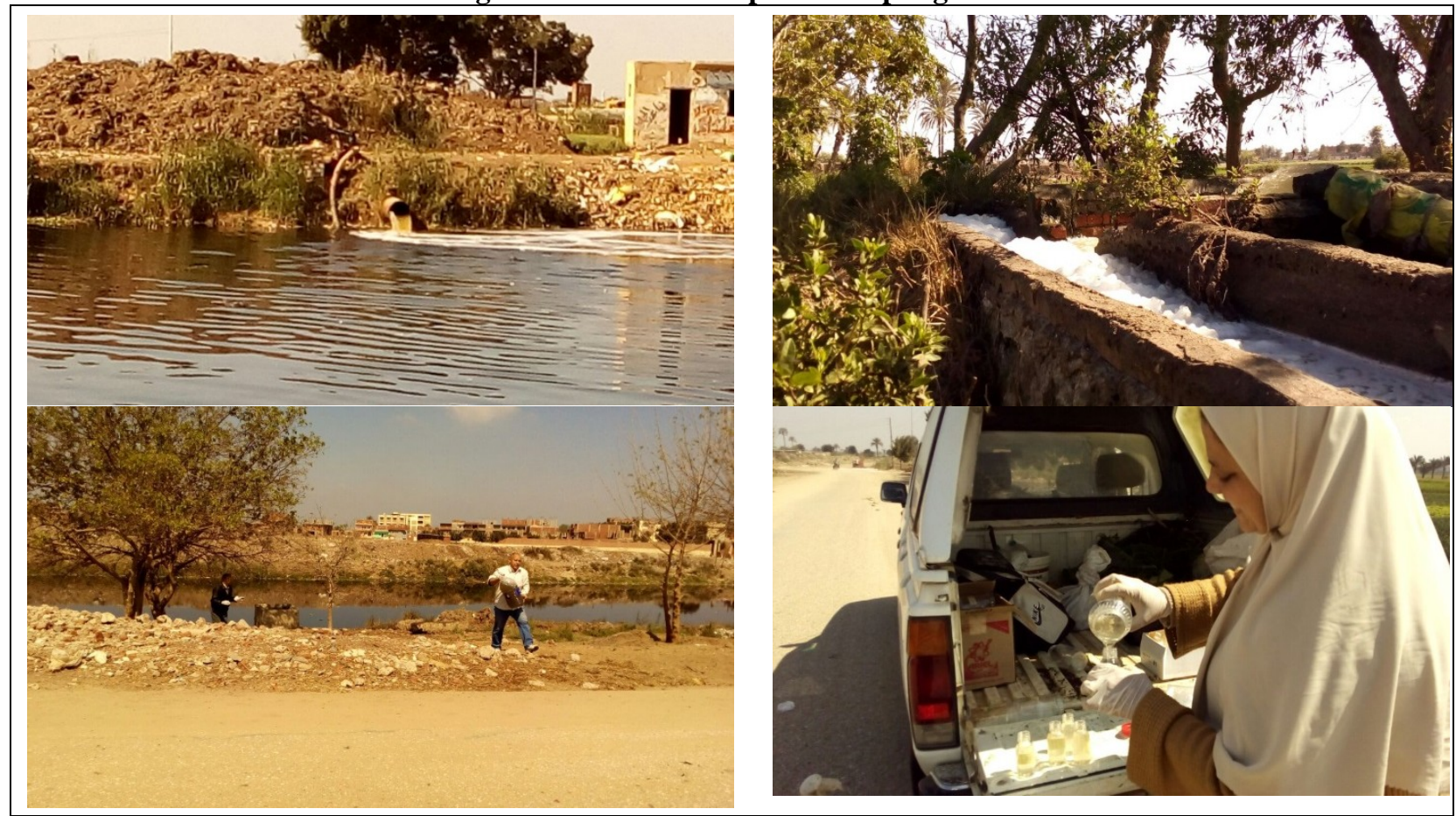

Figure 2. Water sampling and field measurements 
coliform (Marshall,1992).For differentiation of enteric bacteria, sub culturing of water samples using Triple Sugar Iron medium (TSI) was done. On the other hand, the MPN of fecal streptococci was determined using azide dextrose broth at $37^{\circ} \mathrm{C}$ for $48 \mathrm{hr}$ (Marshall,1992), positive tube was indicated by dense turbidity. Counts of Pseudomonas aeruginosa was determined using asparagine agar medium (Yehia and Sabae, 2011).

coliform (Marshall,1992).For differentiation of enteric bacteria, sub culturing of water samples using Triple Sugar Iron medium (TSI) was done. On the other hand, the MPN of fecal streptococci was determined using azide dextrose broth at $37^{\circ} \mathrm{C}$ for $48 \mathrm{hr}$ (Marshall,1992), positive tube was indicated by dense turbidity. Counts of Pseudomonas aeruginosa was determined using asparagine agar medium (Yehia and Sabae, 2011).

Table 1. Studied plants and edible parts consumed

\begin{tabular}{|c|c|c|}
\hline $\begin{array}{l}\text { Usual name } \\
\text { of plant }\end{array}$ & $\begin{array}{l}\text { Scientific name } \\
\text { of plant }\end{array}$ & $\begin{array}{l}\text { Edible part } \\
\text { consumed }\end{array}$ \\
\hline Lettuce & Lactuca sativa & Leaves \\
\hline Wheat & $\begin{array}{l}\text { Triticum } \\
\text { aestivum }\end{array}$ & Cereals \\
\hline Onion & Allium cepa & Leaves \\
\hline Garlic & Allium sativum & Tubers \\
\hline Cabbage & $\begin{array}{l}\text { Brassica } \\
\text { oleracea }\end{array}$ & Leaves \\
\hline Bean & Vicia faba & Cereals \\
\hline Dill & $\begin{array}{l}\text { Anethum } \\
\text { graveolens }\end{array}$ & Leaves \\
\hline Red Pepper & $\begin{array}{l}\text { Capsicum } \\
\text { аппиит }\end{array}$ & Fruits \\
\hline Tomato & $\begin{array}{c}\text { Solanum } \\
\text { lycopersicum }\end{array}$ & Fruits \\
\hline Eggplants & $\begin{array}{c}\text { Solanum } \\
\text { melongena }\end{array}$ & Fruits \\
\hline Parsley & Apium crispum & Leaves \\
\hline Cucumber & Cucumis sativus & Fruits \\
\hline Hibiscus & Malva aegyptia & Leaves \\
\hline Clover & $\begin{array}{c}\text { Trifolium } \\
\text { alexandrinum }\end{array}$ & $\begin{array}{l}\text { Fodder } \\
\text { (Shoots) }\end{array}$ \\
\hline
\end{tabular}

\section{2- Soil analysis}

Chemical and physical analysis of soil: The main chemical and physical properties of the soil samples including $\mathrm{pH}$, electrical conductivity (EC), calcium carbonate content $\left(\mathrm{CaCO}_{3}\right)$, organic matter (O.M), cation exchange capacity (CEC) and clay content were represented in Table (2). They were determined using standard methods mentioned by Cottenie, et al.(1982) and Sparks (1998), Surface area was measured by BET method (Ostafiychuk et al., 2014). Soil samples were analyzed for their total content of heavy metals by filtered soil extracts obtained from digestion of soil samples by $\mathrm{HNO}_{3}, \mathrm{H}_{2} \mathrm{SO}_{4}$ and $60 \% \mathrm{HClO}_{4}$ as outlined by Hesse(1971).

Assessment of heavy metal contamination in agricultural soils:

\section{1- Index of Geoaccumulation}

The index of geoaccumulation (Igeo) actually enables the assessment of contamination by comparing the current and pre-industrial concentrations originally used with bottom sediments (Muller, et al., 1969); it can also be applied to the assessment of soil contamination. The method assesses the degree of metal pollution in terms of seven enrichment classes based on the increasing numerical values of the index. It is computed using the Equation (1) as:

$$
\mathrm{I}_{\text {geo }}=\log _{2} \underline{\mathrm{C}}_{\underline{\mathrm{n}}} 1.5 \mathrm{~B}_{\mathrm{n}}
$$

Where $\mathrm{C}_{\mathrm{n}}$; is the measured concentration of the element in the politic sediment fraction $(<2 \mu \mathrm{m})$ and $B n$ is the geochemical background value in fossil argillaceous sediment (average shale). The constant 1.5 allows us to analyze natural fluctuations in the content of a given substance in the environment as well as very small anthropogenic influences.

Index of geoaccumulation (Igeo) for contamination levels in soil (Muller, et al., 1969)

\begin{tabular}{|c|c|c|}
\hline $\begin{array}{l}\text { Igeo } \\
\text { Class }\end{array}$ & $\begin{array}{c}\text { Igeo } \\
\text { Value }\end{array}$ & Contamination Level \\
\hline 0 & Igeo $\leq 0$ & Uncontaminated \\
\hline 1 & $\begin{array}{c}0< \\
\text { Igeo }< \\
1\end{array}$ & $\begin{array}{l}\text { Uncontaminated/moderately } \\
\text { contaminated }\end{array}$ \\
\hline 2 & $\begin{array}{c}1< \\
\text { Igeo }< \\
2\end{array}$ & Moderately contaminated \\
\hline 3 & $\begin{array}{c}2< \\
\text { Igeo }< \\
3\end{array}$ & $\begin{array}{l}\text { Moderately /strongly } \\
\text { contaminated }\end{array}$ \\
\hline 4 & $\begin{array}{c}3< \\
\text { Igeo }< \\
4\end{array}$ & Strongly contaminated \\
\hline 5 & $\begin{array}{c}4< \\
\text { Igeo }< \\
5\end{array}$ & $\begin{array}{l}\text { Strongly /extremely } \\
\text { contaminated }\end{array}$ \\
\hline 6 & $\begin{array}{c}5< \\
\text { Igeo }\end{array}$ & Extremely contaminated \\
\hline
\end{tabular}

In the present paper we applied the modified calculation based on the equation given by Taylor, et al., (1995), where $C_{n}$ denoted the concentration of a given element in the soil tested, while $B_{n}$ denoted the concentration of elements in the earth's crust (Taylor, et al., 1995). 


\section{Pollution Indices Calculations:}

According to El-Bady, (2016) the values of Canadian soil quality guidelines CSQGs,2007) were used as a reference or background in the equations of pollution indices In these methods any metal not present in CSQGs must be removed from the calculation such as $\mathrm{Fe}$ in this study, where $\mathrm{Fe}$ is not present in CSQGs. Contamination factor $\left(\mathrm{CF}_{(C S Q G s)}\right)$,Pollution load index $\left(P L I_{(C S Q G s)}\right)$ and degree of contamination $\left(\mathrm{Dc}_{(\mathrm{CSQGs})}\right)$ were calculated as following:

\section{Contamination factor $\left(\mathbf{C F}_{(C S Q G s)}\right)$}

$\mathrm{CF}$ is the quotient of concentration of a heavy metal in a sample and the concentration of the same heavy metal in a background or reference material.In these indices, the CSQGs were used as reference or background

$$
\mathrm{CF}_{(\mathrm{CSQGs})}=\mathrm{Mc} / \mathrm{Mc}_{\mathrm{CSQGs}}
$$

Where; CF (CSQGs) is contamination factor by using Canadian soil quality guidelines, $\mathrm{Mc}$ is concentration of metal in collected samples and Mc (CSQGs) is the concentration of metal in CSQGs.

The following terminologies are used to describe the contamination factor:

\begin{tabular}{cc}
\hline Contamination Factor & \\
\hline low contamination & $\mathrm{CF}<1$ \\
$\begin{array}{c}\text { moderate contamination factors } \\
\text { considerable contamination } \\
\text { factors }\end{array}$ & $1 \leq \mathrm{CF}<3$ \\
very high contamination factor. & $\mathrm{CF}<6$ \\
\hline
\end{tabular}

Pollution load index (PLI (CSQGs) )

$P L I_{(C S Q G s)}=\left(C F 1_{(C S Q G s)} \times C F 2_{(C S Q G s)} \times C F 3_{(C S Q G s)}\right.$ $\left.\times \cdots \cdots \times C F n_{(C S Q G s)}\right)^{1 / n}$

PLI ${ }_{\text {(CSQGs) }}$ is Pollution load index by using Canadian soil quality guidelines. The PLI value $>1$ is polluted whereas PLI value $<1$ indicates no pollution (Chakravartyand Patgiri, 2009and Seshanet al.,2010).

Degree of Contamination ( $\left.\mathrm{Dc}_{(\mathrm{CSQGs})}\right)$ :

$$
\sum_{(\mathrm{CSQGs})}=\sum_{1}^{\mathrm{n}} \mathrm{CF}(\mathrm{CSQGs})
$$

Where, Dc ${ }_{(\mathrm{CSQGs})}$ is Degree of Contamination

For the description of the degree of contamination in the study area the following terminologies have been used:

\begin{tabular}{cc}
\hline Degree of contamination & \\
\hline low degree of contamination & $\mathrm{Dc}<7$ \\
moderate degree of contamination; & $7<\mathrm{Dc}<14$ \\
considerable degree of & $14 \leq \mathrm{Dc}<28$ \\
$\quad$ contamination & \\
very high degree of contamination & $\mathrm{Dc}>28$ \\
\hline
\end{tabular}

Where, $n=7=$ the count of the studied heavy metals (after remove Fe,Mn metal).

Pollution Rate $\left(\mathbf{P R}_{(C S Q G s)}\right)$

$$
\mathrm{PR}_{(C S Q G s)}=\left(\sum \mathrm{Mc}\right)_{\text {sample }} /\left(\sum \mathrm{Mc}_{(C S Q G s)) \text { background }}\right.
$$

Where; $\mathrm{Mc}$ is the concentration of metals in collected sample, $\mathrm{Mc}_{(\mathrm{CSQGs})}$ concentration of metal in Canadian soil quality guidelines as background. If the $\mathrm{PR}$ is less than 1 the PR is very low Pollution Rate, If 1 $\leq \mathrm{PR}<2$ is low $\mathrm{PR}$, If $\mathrm{PR} \geq 2$ is high rate.

\section{Plant analysis:}

The collected agricultural plant samples were thoroughly washed with distilled water,then samples were oven dried at $60 \mathrm{C}^{0}$ and ground prior for analysis,the plant parts powder $0.5 \mathrm{~g}$ was digested according to Norvell (1984) using a mixture of $\mathrm{H}_{2} \mathrm{SO}_{4}$, $\mathrm{HNO}_{3}$ and $\mathrm{HClO}_{4}$ to determine essential and heavy metals analysis. Heavy metals and essential metals $\mathrm{Cu}$, $\mathrm{Fe}, \mathrm{Mn}, \mathrm{Ni}, \mathrm{Zn}, \mathrm{B}, \mathrm{Co}, \mathrm{Cr}, \mathrm{Pb}, \mathrm{Cd}, \mathrm{V}, \mathrm{Ba}, \mathrm{Al}$ and $\mathrm{Mo}$ plant samples were analyzed using Inductively Coupled Argon Plasma, ICAP 6500 Duo, Thermo Scientific, England. $1000 \mathrm{mg} / \mathrm{l}$ multi-element certified standard solution, Merck, Germany was used as stock solution for instrument standardization. For determination of nitrate, $0.4 \mathrm{~g}$ of dried ground plant samples was extracted by $(0.025 \mathrm{M}$ aluminum sulfate $\left.\mathrm{AL}_{2}\left(\mathrm{SO}_{4}\right)_{3} \cdot 6 \mathrm{H}_{2} \mathrm{O}\right)$ according to Baker and smith, (1969) then distillated by using a modified Micro-Kjeldahl method, as described by Peach and Tracey (1956).

\section{RESULTS AND DISCUSSION}

\section{1-Water analysis}

\section{Chemical analysis for water samples}

As shown in Table (2), the salinity of collected water samples ranged from 343 to $3810 \mathrm{ppm}$ and the majority $(60 \%)$ of the collected samples were fresh while the rest samples $(40 \%)$ were brackish water, according to WHO, (2001).

It is clear from table (3) that, soluble heavy metals and trace elements in water samples collected along the Bahr El-Bakr drain showed no high concentration of any heavy metals in all collected water samples except sample No.6 which possessed by aluminum (10.67 $\mathrm{mg} / \mathrm{l})$ and iron $(8.767 \mathrm{mg} / \mathrm{l})$ high concentrations. On other hand, heavy metals and trace elements in the digested water samples suffered a significant rise and violation values, that the concentration range of $\mathrm{Al}$ (48.765 to $4.3085 \mathrm{mg} / \mathrm{l}$ ) were exceeded the permissible limit $(3.0 \mathrm{mg} / \mathrm{l})$ set by the Egyptian Law 4/1994 revised in 2009 for irrigation water while samples numbers 1,3 , $5,6,7,8,9 \& 10$ were exceeded the Recommended limits of long term use for irrigation (Rowe and AbdelMagid, 1995). Cadmium and cobalt (0.05, $2.00 \mathrm{mg} / \mathrm{l})$ were found below the permissible limitof 


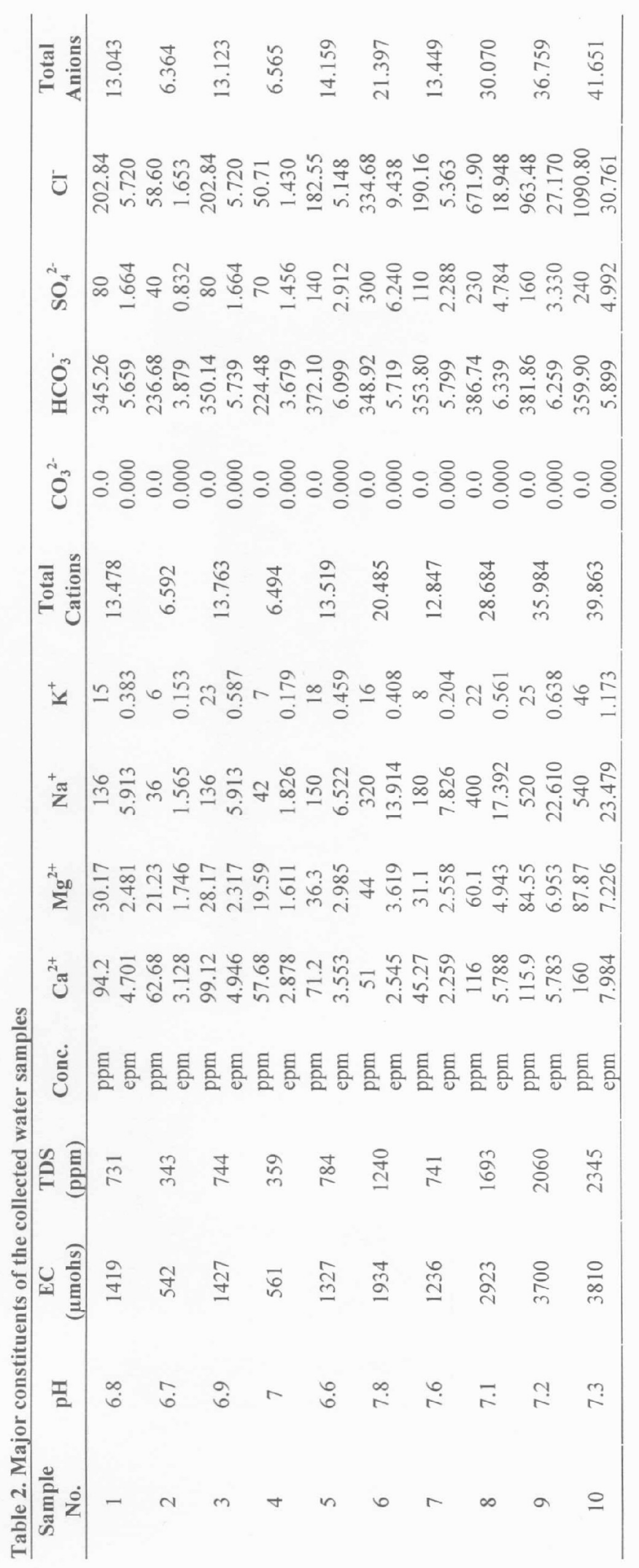




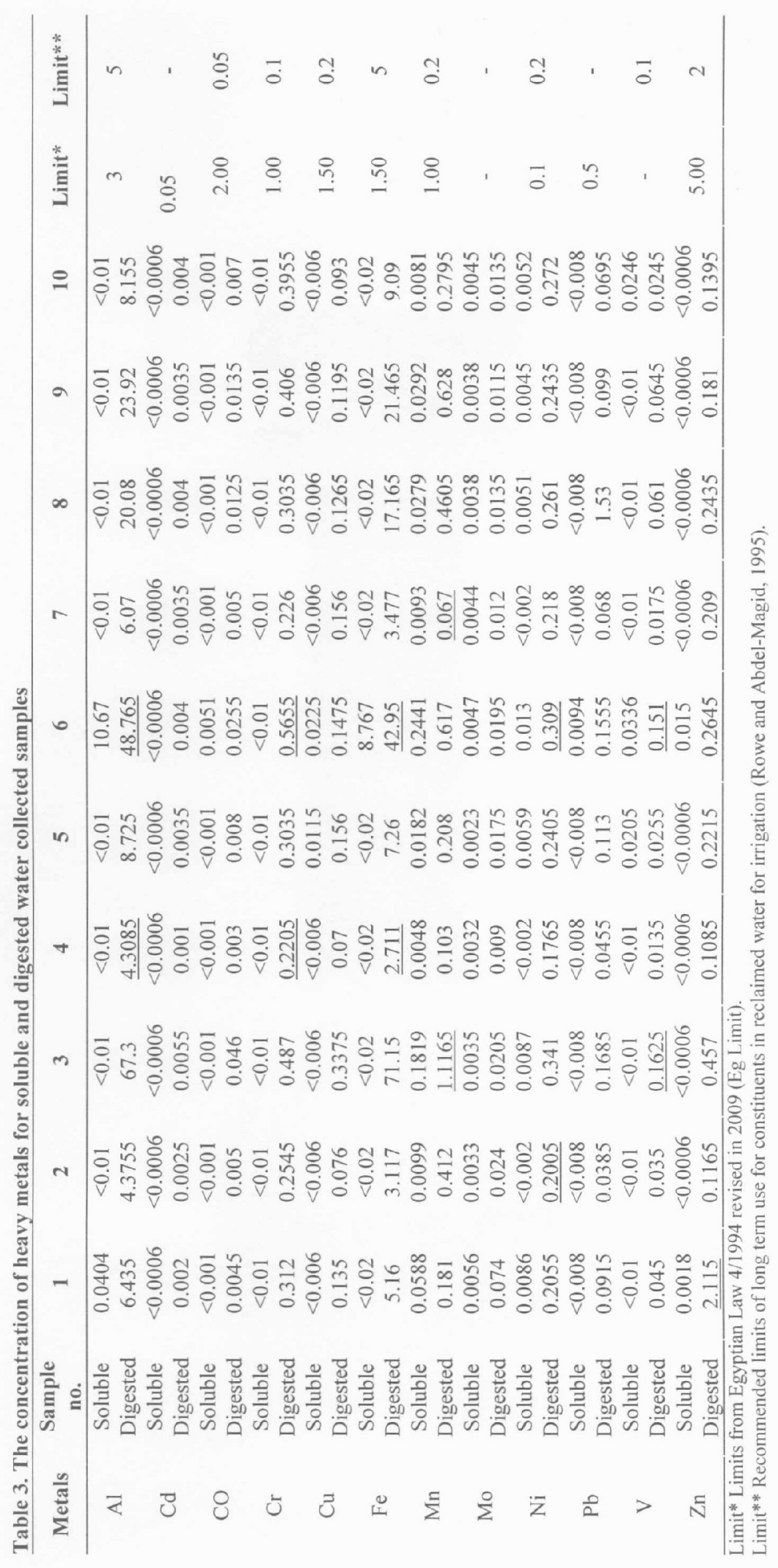


Egyptian Law 4/1994 revised in 2009 for all studied samples. The recorded chromium contents were ranged from 0.5655 to $0.2205 \mathrm{mg} / \mathrm{l}$ below Egyptian Limit, but exceeded the admissible limit for long use of irrigation (0.2 $\mathrm{mg} / \mathrm{l})$ set by (Rowe and Abdel-Magid, 1995). Copper was found below the permissible limit $(0.2$ $\mathrm{mg} / \mathrm{l}$ ) of Rowe and Abdel-Magid, (1995) for all samples with the exclusion of sample No. by $3(0.3375 \mathrm{mg} / \mathrm{l})$. The maximum amount of iron was found $(42.95 \mathrm{mg} / \mathrm{l})$ in sample No.6 and the lowest one 2.711 in sample No.4 that all of them were exceeded the allowable limit $(1.5 \mathrm{mg} / \mathrm{l})$ set by (Eg. Limit). The highest concentration of $\mathrm{Mn}(1.1165 \mathrm{mg} / \mathrm{l})$ in sample No.3 that exceeded the permissible limit $(1.0 \mathrm{mg} / \mathrm{l})$ set by the $\mathrm{Eg}$. Limit and the lowest concentration were found $(0.067 \mathrm{mg} / \mathrm{l})$ that is below the recommended limit. $(0.2 \mathrm{mg} / \mathrm{l})$ set by Rowe and Abdel-Magid, (1995). Nickel contents of all samples showed an increase than $(0.2 \mathrm{mg} / \mathrm{l})$ set by Rowe and Abdel-Magid, (1995) except sample No.4 by $(0.1765 \mathrm{mg} / \mathrm{l})$. The highest concentrations of vanadium were found 0.1625 and $0.151 \mathrm{mg} / \mathrm{l}$ in samples No.3 \& 6 that exceeded the permissible limit $(0.1 \mathrm{mg} / \mathrm{l})$ set by the Rowe and Abdel-Magid, (1995). Zinc and lead were found below the recommended limit for all samples except for sample No.1 (2.115 mg/l in $\mathrm{Zn})$ and sample No. $8(1.53 \mathrm{mg} / \mathrm{l}$ in $\mathrm{Pb})$. The huge difference between soluble and digested heavy metals contents may be due to the high tendency of these metals to hold and adhere with any organic material presence in wastewater especially presence in drain. Abdel-Azeem, et al., (2007) studied heavy metal concentration of irrigated Bahr El-Bakr drain water samples and they found the mean contents of $\mathrm{Zn}, \mathrm{Cu}, \mathrm{Mn}, \mathrm{Cd}, \mathrm{Pb}$ and $\mathrm{Co}$ were $124.25,215.50,338.75,56.58,395.75$ and $534.42 \mathrm{mg} / \mathrm{l}$ ;respectively. These results confirmedand explained our assumptions in this section of study.

From Table (4), the concentrations of nitrate were safe and under the permissible limit $(45 \mathrm{mg} / \mathrm{l})$. On the other hand, there are high concentrations of the organic pollutants in the collected water samples. These organic pollutants represented by both TOC and COD. The TOC concentration ranged from 40.2 to $146.45 \mathrm{ppm}$. While the concentration of COD had a wide range that varied from 36.9 to $240 \mathrm{ppm}$, the COD concentration of $60 \%$ of the collected samples exceeds the permissible limits $100 \mathrm{mg} / \mathrm{l}$ set by the Egyptian law 48/1982 as maximum permissible limit for drain water before discharging into agricultural irrigation water (MWRI, 2009).

Microbial investigation of water samples:Microbiological examination of the water samples from selected sites indicated that sites 1, 2, 4, 8,
9, 10 and 11 were highly polluted and not suitable for irrigation especially for edible plants to be eaten uncooked but can be used for tree irrigation. This is indicated by the numbers of the total viable count (TVC) and fecal coliform in the water sites which ranged between $8.2 \times 10^{2}$ and $34.8 \times 10^{2} \mathrm{CFU} / \mathrm{ml}$ and from 360 to $980 \mathrm{MPN} / 100 \mathrm{ml}$, respectively as in Table (5). These results was compatible with that of organic pollution and COD .Fluctuations in bacterial concentration were positively correlated $(\mathrm{r}=0.86, \mathrm{P}$ less than 0.05) with total organic carbon concentrations in the river water (Geeseyand Costerton, 1979). At the same time, sites 3 and 5 recorded very high fecal coliform number (1200 MPN /100 ml) which exceeds the recommended level in irrigation water and so it was not suitable to irrigation of any plants or trees. According to WHO Guide (World Health Organization,2006), the recommended level for irrigation of vegetables likely to be eaten uncooked was $200 \mathrm{MPN} / 100 \mathrm{ml}$ and irrigation of ornamental fruit trees and fodder crops was $1000 \mathrm{MPN} / 100 \mathrm{ml}$. Fecal indicator bacteria such as total coliform, fecal coliform and streptococci are utilized worldwide to measure health hazards, their presence warns of the potential presence of disease causing organisms and should alert the person responsible for the water to take precautionary action (Sanders et al.,2005). Moreover, the counts of pathogenic bacteria Pseudomonas aeruginosa ranged from 0 to $41 \mathrm{CFU} / \mathrm{ml}$ while differentiation of enteric bacteria with TSI revealed the presence of different pathogenic microbes like:Salmonella sp. in sites 3,5 and 8 and Shigellasp. in sites 3 and 5 only. Abdel-Wahaab and Badawy, (2004) mentioned that the water in the drains is currently of poor quality due to pollution from municipal and agriculture sources. There may still be at risk of diarrheal disease for adults and school-aged rural children are in direct contact with the partially treated wastewater at a level of $10^{3}-10^{4} \mathrm{FC} / 100 \mathrm{ml}$ and reduced

Table 4. The concentrations of $\mathrm{NO}_{3}^{-}$, TOC and COD in collected samples

\begin{tabular}{ccccc}
\hline Sample no. & NO $_{\mathbf{3}}, \mathbf{m g} / \mathbf{l}$ & TOC, $\mathbf{~ m g} / \mathbf{l}$ & COD, $\mathbf{~ m g / l}$ \\
\hline 1 & 30.80 & 51.69024 & 73.9 \\
2 & 15.40 & 60.30528 & 73.9 \\
3 & 28.00 & 146.45568 & 36.9 \\
4 & 8.40 & 111.99552 & 110 \\
5 & 36.40 & 51.69024 & 110 \\
6 & 36.40 & 77.53536 & 137 \\
7 & 11.2 & 40.2356 & 72 \\
8 & 39.2 & 68.92032 & 206 \\
9 & 33.6 & 43.0752 & 240 \\
10 & 16.8 & 60.30528 & 170 \\
\hline
\end{tabular}


Table 5. Microbial examination of water samples collected along Bhar El- Bakr drain during summer and winter 2017

\begin{tabular}{|c|c|c|c|c|c|c|}
\hline $\begin{array}{l}\text { Location } \\
\text { number }\end{array}$ & $\begin{array}{l}\text { TVC } \times 10^{2} \\
(\mathrm{CFU} / \mathrm{ml})\end{array}$ & $\begin{array}{c}\text { Total coliform } \\
(\mathrm{MPN} \\
/ 100 \mathrm{ml}) \\
\end{array}$ & $\begin{array}{c}\text { Fecal coliform } \\
(\mathrm{MPN} \\
/ 100 \mathrm{ml}) \\
\end{array}$ & $\begin{array}{c}\text { Fecal } \\
\text { streptococci }\end{array}$ & $\begin{array}{c}\text { Pseudomonas } \\
\text { aeruginosa } \\
\text { (CFU/ml) }\end{array}$ & $\begin{array}{l}\text { Differentiation of } \\
\text { enteric bacteria }\end{array}$ \\
\hline 1 & 20.5 & 620 & 400 & + & 5 & E,coli, Ent. \\
\hline 2 & 12.2 & 510 & 360 & + & 6 & E,coli, Ent. \\
\hline 3 & 36.5 & 1800 & 1600 & + & 41 & $\begin{array}{c}\text { E,coli, Ent., Sall. , } \\
\text { Sh. }\end{array}$ \\
\hline 4 & 32.4 & 1600 & 980 & + & 12 & E,coli,Ent. \\
\hline 5 & 32.7 & 1200 & 1200 & + & 32 & $\begin{array}{c}\text { E,coli, Ent., Sall., } \\
\text { Sh. }\end{array}$ \\
\hline 6 & 25 & 1200 & 920 & + & 26 & E,coli, Ent. \\
\hline 7 & 6 & - & - & - & - & - \\
\hline 8 & 34.8 & 1200 & 960 & + & 16 & E,coli, Ent., Sall. \\
\hline 9 & 15.1 & 960 & 950 & + & 30 & E,coli, Ent. \\
\hline 10 & 8.2 & 960 & 920 & + & 36 & E,coli, Ent. \\
\hline
\end{tabular}

Table 6. Classification of the collected water quality based on suitability for irrigation

\begin{tabular}{|c|c|c|c|c|}
\hline \multirow[t]{2}{*}{ Parameter } & \multirow{2}{*}{ Range } & \multirow{2}{*}{ Classes } & \multicolumn{2}{|c|}{ Study area } \\
\hline & & & No. of samples & $(\%)$ \\
\hline \multirow{5}{*}{$\mathrm{EC}$} & $<250$ & Excellent & 0 & 0 \\
\hline & $250-750$ & Good & 2 & 20 \\
\hline & $750-2000$ & Permissible & 5 & 50 \\
\hline & $2000-3000$ & Doubtful & 1 & 10 \\
\hline & $>3000$ & Unsuitable & 2 & 20 \\
\hline \multirow{5}{*}{$\mathrm{Na} \%$} & $<20$ & Excellent & 0 & 0 \\
\hline & $20-40$ & Good & 2 & 20 \\
\hline & $40-60$ & Permissible & 3 & 30 \\
\hline & $60-80$ & Doubtful & 5 & 50 \\
\hline & $>80$ & Unsuitable & 0 & 0 \\
\hline \multirow[t]{2}{*}{ MR } & $<50$ & Suitable & 7 & 70 \\
\hline & $>50$ & Unsuitable & 3 & 30 \\
\hline \multirow{4}{*}{$\mathrm{TH}$} & $<75$ & Soft & 0 & 0 \\
\hline & $75-150$ & Moderately & 0 & 0 \\
\hline & $150-300$ & Hard & 3 & 30 \\
\hline & $>300$ & Very Hard & 7 & 70 \\
\hline \multirow{3}{*}{ RSC } & $<1.25$ & Safe & 10 & 100 \\
\hline & $1.25-2.5$ & Marginally suitable & 0 & 0 \\
\hline & $>2.5$ & Not Suitable & 0 & 0 \\
\hline \multirow{5}{*}{ SAR } & $<20$ & Excellent & 10 & 100 \\
\hline & $20-40$ & Good & 0 & 0 \\
\hline & $40-60$ & Permissible & 0 & 0 \\
\hline & $60-80$ & Doubtful & 0 & 0 \\
\hline & $>80$ & Unsuitable & 0 & 0 \\
\hline \multirow[t]{2}{*}{$\mathrm{KI}$} & $<1$ & Suitable & 5 & 50 \\
\hline & $>1$ & Unsuitable & 5 & 50 \\
\hline \multirow{3}{*}{ Fecal contamination } & $>1000 \mathrm{cfu} / 100 \mathrm{ml}$ & Unsuitable & 2 & 20 \\
\hline & $200-1000 \mathrm{cfu} / 100 \mathrm{ml}$ & Suitable only for trees and fodders & 7 & 70 \\
\hline & $<200 \mathrm{cfu} / 100 \mathrm{ml}$ & Suitable & 1 & 10 \\
\hline
\end{tabular}

$\overline{\mathrm{EC} \text {; Electrical conductivity ( } \mu \text { mohs), Na\%; Sodium percentage, MR; Magnesium ratio, TH; Total hardness RSC; Residual sodium }}$ carbonate, SAR; Sodium adsorption ratio, KI; Kelly's index. 
guideline level of $10^{3} \mathrm{FC} / 100 \mathrm{ml}$ would be safer and also reduce the risks of epidemic infections (WHO, 2001). On the other hand, only site number 7 was notcontaminated which recorded TVC of $6 \times 10^{2}$ $(\mathrm{CFU} / \mathrm{ml})$ and free from fecal coliforms and other pathogens and it can be used for irrigation of all plant types without any precaution.

Also, the evaluation of the collected water quality for the irrigation suitability was studied using the seven parameters; EC, Na\%, MR, TH, RSC, SAR, KI and fecal contamination as shown in Table (6).

\section{2- Soil analysis}

Chemical and physical characteristics of the soils:The mainvarious physico-chemical characteristics of studied soils were illustrated in Table (7). Among significant variables that control the distribution and enrichment of heavy metals in the soils are soil $\mathrm{pH}$, soil texture, amount of organic matter in the soil and the cation exchange capacity (Huang and Lin, 2003), the results showed that soil $\mathrm{pH}$ ranged in a narrow interval (6.63 to 7.39) suggested that soil is mostly in neutral to sub-acidic condition, which can be attributed to the low content of carbonate and high percentage of organic matter in addition to high content of surface area which ranged from 469.7 to $516.9\left(\mathrm{~m}^{2} / \mathrm{g}\right)$ with clay texture in soil, while cation exchange capacity was ranged from

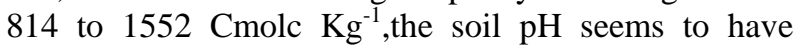
higher effect on the solubility or metals retention in soil; the greater retention and lower solubility of metal occurs at high soil pH (Škrbić and Miljević, 2002).

Heavy metals pollution (Environmental Assessment):Results represents in Table (8) imply that total heavy metals concentrations in the studied soils ranged between 7355 and $18150 \mathrm{mg} / \mathrm{kg}$ for Fe; 133.76 to $90.45 \mathrm{mg} / \mathrm{kg}$ for $\mathrm{Zn} ; 25.58$ to $56.40 \mathrm{mg} / \mathrm{kg}$ for $\mathrm{Cu}$; 40.21 to $49.77 \mathrm{mg} / \mathrm{kg}$ for $\mathrm{Pb} ; 11.75$ to $13.25 \mathrm{mg} / \mathrm{kg} \mathrm{Cd}$; 22.30 to $39.23 \mathrm{mg} / \mathrm{kg}$ for $\mathrm{Ni} ; 21.00$ to $32.72 \mathrm{mg} / \mathrm{kg}$ for $\mathrm{Co}$; however, the concentration of $\mathrm{Cr}$ in different soils were ranged between 15.28 to $49.78 \mathrm{mg} / \mathrm{kg}$. In other words, the deciding order of heavy metals measured in these soils could be arranged as follows: $\mathrm{Fe}>\mathrm{Zn}>\mathrm{Pb}>$ $\mathrm{Cu}>\mathrm{Cr}>\mathrm{Ni}>\mathrm{Co}>\mathrm{Cd}$.

Table 7. Some chemical and physical properties of the studied soils

\begin{tabular}{|c|c|c|c|c|c|c|c|c|c|c|}
\hline \multirow{2}{*}{$\begin{array}{c}\text { Sample } \\
\text { no. }\end{array}$} & \multirow[t]{2}{*}{ pH } & \multirow{2}{*}{$\begin{array}{c}\mathrm{EC} \\
\left(\mathrm{dSm}-{ }^{1}\right)\end{array}$} & \multirow{2}{*}{$\begin{array}{c}\text { CEC } \\
\left(\mathrm{Cmolc}^{2}\right. \\
\left.\mathrm{Kg}^{-1}{ }^{1}\right) \\
\end{array}$} & \multirow{2}{*}{$\begin{array}{c}\text { Total } \\
\mathrm{CaCO}_{3} \\
(\%) \\
\end{array}$} & \multirow{2}{*}{$\begin{array}{l}\text { OM } \\
(\%)\end{array}$} & \multirow{2}{*}{$\begin{array}{c}\text { Surface } \\
\text { area } \\
\left(\mathrm{m}^{2} / \mathbf{g}\right)\end{array}$} & \multicolumn{3}{|c|}{$\begin{array}{c}\text { Partical size } \\
\text { distribution }(\%)\end{array}$} & \multirow{2}{*}{$\begin{array}{l}\text { Texture } \\
\text { class }\end{array}$} \\
\hline & & & & & & & Sand & Silt & Clay & \\
\hline 2 & 7.01 & 0.72 & 854 & 4.6 & 6.50 & 480 & 58.8 & 18 & 23.2 & SCL \\
\hline 3 & 6.63 & 1.74 & 1552 & 4.6 & 5.06 & 516.9 & 24.8 & 28 & 47.2 & Clay \\
\hline 4 & 7.35 & 2.29 & 1090 & 5.06 & 6.10 & 486.9 & 40.8 & 14 & 45.8 & Clay \\
\hline 6 & 7.12 & 2.51 & 1484 & 4.14 & 5.66 & 505.3 & 42.8 & 10 & 47.2 & Clay \\
\hline 7 & 7.39 & 2.56 & 814 & 2.3 & 7.57 & 469.7 & 90.8 & 2 & 7.2 & Sand \\
\hline 9 & 6.73 & 10.26 & 1146 & 7.82 & 7.97 & 492.7 & 23.8 & 30 & 47.2 & Clay \\
\hline
\end{tabular}

SCL: Sand clay loam
Table 8.Total concentrations of heavy metals in Bahr El-Bakr selected soils (mg/kg)

\begin{tabular}{ccccccccc}
\multicolumn{2}{c}{ Table 8. Total concentrations of heavy metals in Bahr El-Bakr selected soils (mg/kg) } \\
\hline No. & $\mathbf{F e}$ & $\mathbf{Z n}$ & $\mathbf{C u}$ & $\mathbf{P b}$ & $\mathbf{C d}$ & $\mathbf{N i}$ & $\mathbf{C o}$ & $\mathbf{C r}$ \\
\hline 2 & 7355.00 & 72.02 & 32.91 & 49.77 & 13.25 & 24.81 & 24.35 & 26.56 \\
3 & 16055.00 & 89.80 & 53.61 & 40.21 & 13.01 & 35.17 & 31.79 & 33.87 \\
4 & 11520.00 & 84.87 & 44.94 & 43.94 & 12.45 & 35.58 & 28.38 & 34.64 \\
6 & 11525.00 & 63.55 & 51.19 & 42.81 & 11.98 & 30.96 & 28.24 & 49.78 \\
7 & 11709.50 & 33.76 & 25.58 & 47.70 & 11.75 & 22.30 & 21.00 & 15.28 \\
9 & 18150.00 & 90.45 & 56.40 & 43.18 & 12.69 & 39.23 & 32.72 & 45.01 \\
Max & 18150.00 & 90.45 & 56.40 & 49.77 & 13.25 & 39.23 & 32.72 & 49.78 \\
Min & 7355.00 & 33.76 & 25.58 & 40.21 & 11.75 & 22.30 & 21.00 & 15.28 \\
Average & 12719.08 & 72.41 & 44.10 & 44.60 & 12.52 & 31.34 & 27.75 & 34.19 \\
CSQG & - & 200 & 63 & 70 & 1.4 & 50 & 40 & 64 \\
(EU, 2002) & - & 300 & 140 & 300 & 3 & 75 & - & 150 \\
Average upper earth & 30890 & 52 & 14.3 & 17 & 0.1 & 18.6 & 11.6 & 35 \\
crust & & & & & & & &
\end{tabular}

Average shale, after Turekian and Wedepohl (1961) -Average upper earth crust, after Wedepohl (1995). CSQG of Agricultural soil Canadian Soil Quality Guidelines (CSQG), (2007). European Union Standards European Union, (2002) 
According to documents of Canadian soil quality guidelines (CSQG, 2007) and European Union, (2002) as well as the average of upper earth crust Wedepohl (1995), Fe concentrations in the study areas were morethan the normal average of upper earth crust values with exception noted in samples No. 2 and 7, concerning $\mathrm{Zn}$ concentrations in the study areas, results indicated that the concentrations are lower than that of CSQG, EU. However, the same values are higher than the average upper earth crust values of Wedepohl (1995)In general Zn usually remains adsorbed to soil, in some studies; however, they reported that at waste disposal sites, $\mathrm{Zn}$ could be leaching. The lower concentrations of $\mathrm{Zn}$ than the safe limits of CSQG and EU at most sites might be due to the continuous removal of heavy metals by the edible crops grown in this area and may also due to leaching of heavy metals into the deeper layer of the soil and to the ground water. $\mathrm{Cu}$ concentrations in the study soils were less than the range values documented by CSQG and EU Values and more than the average of upper earth crust of Wedepohl (1995). Regarding Co concentrations in the study soils, results indicated that the high values of pollutants compared to CSQG or EU values and in average of upper earth crust of Wedepohl (1995). Lead concentration values of the study areas were lower than the values of CSQG or EU and higher than the average upper earth crust values of Wedepohl (1995). Nickel concentrations in the soil samples of the study areas (table 2) are higher in their values compared to the average upper earth crust values of Wedepohl (1995). Nickel occurs in soils as a result of the weathering of the parent rock McGrath, (1995). In addition, agricultural fertilizers applied, especially phosphates, are also a significant source of nickel in soil ecosystem, however, it is unlikely to build-up in soil in the long term from their use McGrath, (1995).The irrigation by Bahr El-Bakr wastewater and heavily uses of agricultural fertilizers in the studied areas could be the main source of $\mathrm{Ni}$ accumulation. Cadmium concentrations in the soil of the study area are higher than that of CSQG, EU and average upper earth crust of Wedepohl (1995). Cadmium is regarded as one of the most toxic elements in the environment. Naturally, $\mathrm{Cd}$ occurs in soils as a result of the weathering of the parent rock Alloway, (1995). Atmospheric deposition phosphatic fertilizers are important source of cadmium pollution ATSDR, (2008). Cadmium is higher in the study area due to the uses of phosphatic fertilizers, irrigation by untreated wastewater of Bahr El-Bakr Darin. Chromium concentrations represent in table 2 showed that in the study area are less than that of CSQG, EU values and average upper earth crust of
Wedepohl (1995). Iron, chromium, copper, zinc may be lower in some sites due to the continuous removal of heavy metals by the edible crops grown in these areas and also due to leaching of heavy metals into the deeper layer of the soil and to the ground water. It can be concluded that, heavy metals content as cadmium, lead, nickel were high may be due to lower $\mathrm{pH}$, clay texture and high organic matter. Heavy metals have a strong affinity for organic content, clay and silt fraction because of their high cation exchange capacity (Bodur and Ergin, 1994).

Assessment of heavy metal contamination of agricultural soil:Average Igeo and contamination levels of different metals in soil are given in Table(9). Igeo is distinctly variable and suggests that soil sampling ranged from uncontaminated to strongly/extremely contaminate with respect to the analyzed metals. Igeo revealed that all the soil samples in respect of $\mathrm{Fe}, \mathrm{Zn}, \mathrm{Cu}, \mathrm{Ni}, \mathrm{Co}$ and $\mathrm{Cr}$ fell into (class 0 means uncontaminated). but different for $\mathrm{Pb}$ in the soil sampling points fell in class 2 and the average Igeo was 1.57 indicating moderately contaminated. In the case of $\mathrm{Cd}$ followed Strongly/extremely contaminated index the average Igeo was 5.80, fell into class 6 . This high index is caused mainly by the metallurgical industry; hence its content in the areas affected by industrial activity may be elevated Taylor, et al., (1995).

Data in Table (10) illustrated, the CSQGs were used as reference. Computation of this index revealed the following:

i) The values of $\mathrm{CF}$ for $\mathrm{Zn}, \mathrm{Cu}, \mathrm{Pb}, \mathrm{Ni}, \mathrm{Co}$ and $\mathrm{Cr}$ was less than 1 suggesting that the all soils were low contamination factor of these elements.

ii) The values of $\mathrm{CF}$ ranged from 8.39 to 9.46 for $\mathrm{Cd}$, indicating thatvery high contamination factor in all samples of the studied soils. This means that all soils are highly contaminated with $\mathrm{Cd}$

iii) Likewise, all the soils represented by the studied profiles were low contaminated with all elements Contamination factor $\left(\mathrm{CF}_{(C S Q G s)}\right)$ except for $\mathrm{Cd}$ which was highly contaminated.

iv) All the values of DC ranged from 10.86 to 13.33 that mean the all studied soils hadmoderate degree of contamination for such element.

v) PLI value $<1$ in all soils except number 9 The PLI value $>1$ that mean all soils of these study had no pollution indicates no pollution except the soil number 6 was polluted.

Pollution Rate $\left(\mathbf{P R}_{(\mathrm{CSQGs})}\right)$ : Pollution rate $(\mathrm{PR})$ is a method instead of the ordinary PLI and Dc for determination the pollution in any site with more 
accuracy (Table11). The remove of Fe is very more than any other metals that Fe is not occurred in CSQGs. For all soil samples, the PR is less than 1 that's mean the all soils recoded very low pollution rate.

Microbial investigation for soil samples: Microbial examination of soil in the study area indicated remarkable pollution of the soil in the study area as indicated in Table (12), the count of indicator bacteria ranged from $6.9 \times 10^{5}$ to $56.6 \times 10^{5} \mathrm{CFU} / \mathrm{gm}$ soil, $96-160$ $\times 10^{2}$ and $82-120 \times 10^{2}$ MPN/ gm soil for total viable count (TVC) ,total coliforms (TC) and fecal coliforms (FC), respectively, in addition to the presence of fecal streptococci in all soil samples. High densities of the bacterial TVC andtotal coliforms might derived from the irrigation water contaminated with domestic sewage that find their way to them. High density of FC indicating recent fecal pollution, consequently, pollutants introduced to soil in low amounts may not have an immediate hazard effect, but over time, such pollutants will accumulate and when a specific concentration is reached, harmful effects can occur (Gerba,2000). It is noticed from results that soil samples showed higher microbial contamination compared to irrigation water of the same site. This is attributed to the adsorption of bacterial cells on the soil particles and the availability of organic matter in the soil which provide rich environment for these bacteria (Abdallah et al.,2005). Sediments may contain 100 to 1,000 times the number of fecal indicator bacteria contained in the overlying water (Crabill et al., 1999). However, the number of fungiranged from 4 to $40 \times 10^{3} \mathrm{CFU} / \mathrm{ml}$ in all soils under study. The continuous irrigation of soils with wastewater results in dramatic change in the soil nutritional status, in which may favored certain fungal groups as specific groups of saprotrophic fungiand so, contributes to the contamination of the irrigated soil with fungal pathogens (Shehu et al.,2014).

Table 9.Average Igeo and contamination levels of soil

\begin{tabular}{|c|c|c|c|c|c|c|c|}
\hline \multirow{2}{*}{$\begin{array}{l}\text { Heavy } \\
\text { metals }\end{array}$} & \multicolumn{6}{|c|}{ Average Igeo } & \multirow{2}{*}{ Contamination Level } \\
\hline & 2 & 3 & 4 & 6 & 7 & 9 & \\
\hline $\mathrm{Fe}$ & -3.68 & -2.56 & -3.04 & -3.04 & -3.01 & -2.38 & Uncontaminated \\
\hline $\mathrm{Mn}$ & -2.45 & -1.73 & -1.18 & -1.83 & -2.21 & -2.23 & Uncontaminated \\
\hline $\mathrm{Zn}$ & -0.72 & -0.40 & -0.48 & -0.90 & -1.81 & -0.39 & Uncontaminated \\
\hline $\mathrm{Cu}$ & -1.63 & -0.93 & -1.18 & -0.99 & -1.99 & -0.85 & Uncontaminated \\
\hline $\mathrm{Pb}$ & 1.73 & 1.42 & 1.55 & 1.51 & 1.67 & 1.53 & Moderately contaminated \\
\hline $\mathrm{Cd}$ & 5.88 & 5.85 & 5.79 & 5.73 & 5.71 & 5.82 & Extremely contaminated \\
\hline $\mathrm{Ni}$ & -2.44 & -1.94 & -1.92 & -2.12 & -2.60 & -1.78 & Uncontaminated \\
\hline $\mathrm{Co}$ & -0.89 & -0.50 & -0.67 & -0.67 & -1.10 & -0.46 & Uncontaminated \\
\hline $\mathrm{Cr}$ & -2.98 & -2.63 & -2.60 & -2.08 & -3.28 & -2.22 & Uncontaminated \\
\hline
\end{tabular}

Table 10. Contamination Factor (CF $(C S Q G s)$ ), Pollution load index (PLI (CSQGs)) and Degree of Contamination (Dc $(C S Q G s)$ ) of Bahr EL-Bakr Region

\begin{tabular}{|c|c|c|c|c|c|c|c|c|c|}
\hline \multirow[t]{2}{*}{ Samples } & \multicolumn{7}{|c|}{ Contamination Factor (CF (CSQGs)) } & \multirow[t]{2}{*}{ DC (CSQGs) } & \multirow[t]{2}{*}{ PLI (CSQGs) } \\
\hline & $\mathbf{Z n}$ & $\mathbf{C u}$ & $\mathbf{P b}$ & Cd & $\mathbf{N i}$ & Co & $\mathbf{C r}$ & & \\
\hline 2 & 0.36 & 0.52 & 0.71 & 9.46 & 0.50 & 0.61 & 0.41 & 12.58 & 0.769 \\
\hline 3 & 0.45 & 0.85 & 0.57 & 9.29 & 0.70 & 0.79 & 0.53 & 13.19 & 0.93 \\
\hline 4 & 0.42 & 0.71 & 0.63 & 8.89 & 0.71 & 0.71 & 0.54 & 12.62 & 0.896 \\
\hline 6 & 0.32 & 0.81 & 0.61 & 8.56 & 0.62 & 0.71 & 0.78 & 12.40 & 0.895 \\
\hline 7 & 0.17 & 0.41 & 0.68 & 8.39 & 0.45 & 0.52 & 0.24 & 10.86 & 0.58 \\
\hline 9 & 0.45 & 0.90 & 0.62 & 9.06 & 0.78 & 0.82 & 0.70 & 13.33 & 1.003 \\
\hline
\end{tabular}

Table 11. Pollution Rate of Bahr El-Bakrdrain

\begin{tabular}{cccccccccc}
\hline Samples & Zn & $\mathbf{C u}$ & $\mathbf{P b}$ & $\mathbf{C d}$ & $\mathbf{N i}$ & $\mathbf{C o}$ & $\mathbf{C r}$ & Sum & PR \\
\hline 2 & 72.02 & 32.91 & 49.77 & 13.25 & 24.81 & 24.35 & 26.56 & 243.66 & 0.50 \\
3 & 89.80 & 53.61 & 40.21 & 13.01 & 35.17 & 31.79 & 33.87 & 297.45 & 0.61 \\
4 & 84.87 & 44.94 & 43.94 & 12.45 & 35.58 & 28.38 & 34.64 & 284.80 & 0.58 \\
6 & 63.55 & 51.19 & 42.81 & 11.98 & 30.96 & 28.24 & 49.78 & 278.50 & 0.57 \\
7 & 33.76 & 25.58 & 47.70 & 11.75 & 22.30 & 21.00 & 15.28 & 177.35 & 0.36 \\
9 & 90.45 & 56.40 & 43.18 & 12.69 & 39.23 & 32.72 & 45.01 & 319.67 & 0.65 \\
CSQGs & 200 & 63 & 70 & 1.4 & 50 & 40 & 64 & 488.4 & \\
\hline
\end{tabular}


Table 12.Microbiological examination of Soil samplecollected along Bhar El- Bakr drain during summer and winter 2017

\begin{tabular}{|c|c|c|c|c|c|}
\hline $\begin{array}{l}\text { Location } \\
\text { number }\end{array}$ & $\begin{array}{c}\text { TVC } \times 10^{5} \\
\text { CFU/gm soil }\end{array}$ & $\begin{array}{c}\text { Total coliform } \\
\times 10^{2}(\mathrm{MPN} / \text { gm soil })\end{array}$ & $\begin{array}{c}\text { Fecal coliform } \\
\times 10^{2}(\mathrm{MPN} / \mathrm{gm} \text { soil })\end{array}$ & $\begin{array}{c}\text { Fecal } \\
\text { streptococci }\end{array}$ & $\begin{array}{c}\text { Fungi } \times 10^{3} \\
\text { colony/gm soil }\end{array}$ \\
\hline 2 & 4 & 96 & 82 & + & 21 \\
\hline 3 & 56.6 & 160 & 120 & + & 12 \\
\hline 4 & 32.5 & 140 & 117 & + & 26 \\
\hline 6 & 8.8 & 120 & 96 & + & 4 \\
\hline 7 & 6.9 & 110 & 96 & + & 9 \\
\hline 9 & 31.5 & 96 & 84 & + & 40 \\
\hline
\end{tabular}

\section{3-Plant analysis}

Nitrate contents in edible parts of plants: Data in Table (13) was illustrated the average of nitrate concentration's in the edible parts of thirteen human food including lettuce, hibiscus, onion, garlic, cabbage, bean, dill, red pepper, tomato, eggplant, parsley and cucumber in addition to shoots clover plants act as fodder crops cultivated in soil irrigated by Bahr El-Bakr drain and consumed by Egyptian citizens. It was appeared that the mean concentration of nitrate in this study showed a wide range, with the value from 493.2 $\mathrm{mg} / \mathrm{kg}$ dry weight in leaves of dill plants cultivated in site 6 to $8406 \mathrm{mg} / \mathrm{kg}$ dry weight in leaves of hibiscus plants cultivated in site 2 higher than the results obtained by Nowrouz, et al., (2012) who was found that the mean nitrate contents at the fresh vegetables were ranged from $161 \mathrm{mgNO}_{3}^{-} / \mathrm{kg}$ in cabbage and 1702 $\mathrm{mgNO}_{3}{ }^{-} / \mathrm{kg}$ in leek.In general, leafy vegetables such as hibiscus, cabbage, lettuce, onions, parsley, and dill accumulated higher nitrate contents in their edible parts than wheat, red pepper, tomato, cucumber and bean. It is noted from the previous results that the difference of concentrations of nitrates according to location and cultivated land, due to the difference agricultural practices in this region. Also, these results were going along Kaymak, et al., (2013) which they found out that nitrate accumulation in leafy vegetables such as rocket, spinach has a detrimental impact on human health. While Gangolli et al., (1994) reported that vegetables contain nitrates at varying levels ranging from 1 to $10000 \mathrm{mgNO}_{3}^{-} / \mathrm{kg}$. The level of nitrates varies according to the kind of vegetables. In the other hand, data from this study found out the narrow range of nitrate contents of clover plants from 2297.6 to 4310.1 $\mathrm{mg} / \mathrm{kg}$ dry weight.

There are several factors affecting nitrate accumulation in vegetables, e.g. genetic, environmental (temperature, photoperiod) and agricultural factors (nitrogen doses and chemical forms), the most important factor is soil nitrogen content according as nitrogen fertilization (Santamaria, 2006). Data in this study indicated that the elevation in nitrate contents in the edible parts of collected samples indicating a high content of organic matter in irrigated water and may be the excessive consumption of nitrogenous fertilizers. There are various standard for maximum concentration on nitrate in the vegetables. For instance, European Union has suggested the maximum amount of nitrate concentration for lettuce in hydroponic about 3500 $\mathrm{mg} / \mathrm{kg}$ in spring farming and about $4500 \mathrm{mg} / \mathrm{kg}$ in fall farming. (Peyvast, 2006). Based on this, data from this study indicated that leaves of hibiscus plants accumulated $8406 \mathrm{mg} / \mathrm{kg}$. Generally, the maximum amount of nitrate entering human body should not exceed $3.65 \mathrm{mg}$ per $\mathrm{kg}$ of human body a day(Malakuti and bybourdi, 2004, Aly and Abou Elsoued, 2009).

Trace and heavy metal content in plants:The concentrations of metals by $\mathrm{mg} / \mathrm{kg}$ dry weight in selected edible parts of plants grown in soils irrigated by Bahr El-Bakr drain water are shown in Table (13\&14). Generally metal concentrations in leaves, cereal, fruits tubers of edible parts of plants and shoots of clover plants decreased in the order $\mathrm{Fe}>\mathrm{Al}>\mathrm{Zn}>\mathrm{Cu}>\mathrm{Mn}>\mathrm{B}>\mathrm{Ni}>\mathrm{Cr}>\mathrm{Pb}>\mathrm{Ba}>\mathrm{V}>\mathrm{Mo}>\mathrm{Co}>\mathrm{Cd}$ in all studied plant samples. The concentrations of $\mathrm{Al}$ in leaves of edible parts of plants were ranged from 198.15 $\mathrm{mg} / \mathrm{kg}$ dry weight in cabbage site 4 to $134.7 \mathrm{mg} / \mathrm{kg}$ dry weight in onions site 2 and site 9, in cereals from 114.6 $\mathrm{mg} / \mathrm{kg}$ dry weight in bean site 4 to $202.8 \mathrm{mg} / \mathrm{kg}$ dry weight in wheat site 3 , in fruits $76.85 \mathrm{mg} / \mathrm{kg}$ dry weight in red pepper site 7 to $460.55 \mathrm{mg} / \mathrm{kg}$ dry weight in tomato site 6 , in tubers of garlic 70.1 to $140.9 \mathrm{mg} / \mathrm{kg}$ dry weight in sites 4 and 3 ;respectively. While shoots of clover plants ranged from $280 \mathrm{mg} / \mathrm{kg}$ dry weight cultivated in site 9 to $651.5 \mathrm{mg} / \mathrm{kg}$ dry weight in site 4 . Levels of $\mathrm{Al}$ are rarely determined in food studies, the results of this study indicated that the concentration of $\mathrm{Al}$ was above $100 \mathrm{mg} / \mathrm{kg}$ in $86 \%$ of samples. These was higher than the levels found by Scancar et al., 2004 in vegetables $(<30 \mathrm{mg} / \mathrm{kg})$ and Ondo, et al., (2013) in edible parts of some food crops which ranged from 24 $181,63-300$ and $96-301 \mathrm{mg} / \mathrm{kg}$ dry weight in for fruits, leaves and tubers ;respectively. Iron concentrations in food crops ranged between 107.95 to $1284 \mathrm{mg} / \mathrm{kg}$ dry weight and in clover as fodder crops from 359.5 to 1293 $\mathrm{mg} / \mathrm{kg}$ dry weight. Generally, the major sink of iron found in leaves. These results were along with Ravet et 
al., (2009). Fe toxicity in plants occurs when they accumulate greater than $300 \mathrm{mg} / \mathrm{kg}$ of $\mathrm{Fe}$ ( $\mathrm{Li}$ et al., 2006). The Fe contents leafy edible plants like lettuce, dill, parsley and hibiscus under study were extremely higher than the FAO/WHO, (2001) safe limit of 425.00 $\mathrm{mg} / \mathrm{kg}$.

The highest level of $\mathrm{Pb}$ in this study was found in dill (ranged from 3.27 to $24.365 \mathrm{mg} / \mathrm{kg}$ dry weight and the lowest contents in the cereal of wheat plants in all sites except samples collected from site 4, while in clover which ranged from 1.755 to $11.94 \mathrm{mg} / \mathrm{kg}$ dry weight. The high levels of $\mathrm{Pb}$ in some plants may probably be attributed to presence of pollutants in irrigation water, farm soil or due to pollution from the highways traffic (Qui et al., 2000). The Pb contents of the plants in this study were high when compared to the FAO/WHO, (2001) safe limit of $0.3 \mathrm{mg} / \mathrm{kg}$. The study showed that, in the edible parts of plants, $\mathrm{Pb}$ contents are higher than the permissible limit. Thus, $\mathrm{Pb}$ level in the leafy parts of the vegetables examined seems be alarming especially in case of excessive consumption.

Table 13. Mean concentration of heavy metals and Nitrate in the edible parts of vegetables, cereals and clover collected along Bhar El- Bakr drain during summer and winter 2017

\begin{tabular}{|c|c|c|c|c|c|c|c|}
\hline \multirow{2}{*}{ Site } & \multirow{2}{*}{ Plant name } & \multicolumn{6}{|c|}{ Heavy metals and Nitrate (mg/kg D.M.) } \\
\hline & & $\mathbf{P b}$ & Cd & $\mathrm{Cr}$ & Al & $\mathbf{N i}$ & Nitrate \\
\hline \multirow{5}{*}{2} & Lettuce & 2.085 & 0.255 & 5.46 & 384.65 & 3.7 & 3474.5 \\
\hline & Wheat & 1.815 & 0.25 & 5.66 & 127.7 & 3.46 & 1793.3 \\
\hline & Clover & 1.755 & 0.175 & 8.47 & 1161 & 3.83 & 2342.5 \\
\hline & Hibiscus & 2.2 & 0.31 & 7.545 & 1155 & 4.535 & 8406.0 \\
\hline & Onion & 8.755 & 0.235 & 4.915 & 134.7 & 2.745 & 437.1 \\
\hline \multirow{4}{*}{3} & Clover & 10.04 & 0.215 & 5.19 & 452.15 & 3.27 & 2555.4 \\
\hline & Garlic & 8.995 & 0.225 & 5.73 & 140.9 & 3.05 & 1266.5 \\
\hline & Cabbage & 5.97 & 0.205 & 5.28 & 514 & 3.03 & 3138.2 \\
\hline & Wheat & 1.075 & 0.14 & 6.37 & 202.8 & 2.91 & 1125.4 \\
\hline \multirow{8}{*}{4} & Cabbage & 5.17 & 0.245 & 20.285 & 198.15 & 14.065 & 3866.8 \\
\hline & Clover & 3.36 & 0.175 & 6.395 & 651.5 & 3.105 & 2297.6 \\
\hline & Bean & 13.46 & 0.165 & 3.645 & 114.6 & 3.23 & 1143.2 \\
\hline & Lettuce & 9.66 & 0.405 & 9.675 & 1704 & 5.725 & 1860.5 \\
\hline & Dill & 24.365 & 0.295 & 6.19 & 445.4 & 3.835 & 3519.3 \\
\hline & Onion & 7.755 & 0.205 & 5.46 & 98.95 & 2.66 & 1072.4 \\
\hline & Garlic & 1.97 & 0.19 & 4.235 & 70.1 & 2.495 & 2622.7 \\
\hline & Wheat & 12.845 & 0.205 & 7.85 & 156.1 & 2.67 & 521.3 \\
\hline \multirow{10}{*}{6} & Clover & 11.27 & 0.13 & 3.625 & 350.75 & 3.03 & 4310.1 \\
\hline & Lettuce & 3.06 & 0.325 & 5.485 & 565.5 & 3.895 & 1288.6 \\
\hline & Hibiscus & 0.64 & 0.275 & 5.235 & 619 & 3.385 & 4819.4 \\
\hline & Red pepper & 13.38 & 0.165 & 4.275 & 246.2 & 2.74 & 560.4 \\
\hline & Garlic & 1.66 & 0.165 & 4.485 & 89.85 & 2.345 & 1726.2 \\
\hline & Bean & 1.815 & 0.25 & 5.66 & 127.7 & 3.46 & 1232.9 \\
\hline & Wheat & 1.93 & 0.235 & 5.765 & 186.1 & 2.64 & 1333.8 \\
\hline & Onion & 4.04 & 0.22 & 4.12 & 131.1 & 2.44 & 1480.1 \\
\hline & Tomato & 3.535 & 0.275 & 5.715 & 460.55 & 6.985 & 1445.8 \\
\hline & Dill & 18.83 & 0.265 & 9.82 & 367.65 & 4.67 & 493.2 \\
\hline \multirow{4}{*}{7} & Eggplant & 5.45 & 0.155 & 1.96 & 87.15 & 1.99 & 2297.6 \\
\hline & Parsley & 19.18 & 0.725 & 10.38 & 461.05 & 5.835 & 3530.5 \\
\hline & Cucumber & 16.475 & 0.305 & 6.705 & 189.9 & 5.775 & 1758.6 \\
\hline & Red Pepper & 10.105 & 0.165 & 3.475 & 76.85 & 3.865 & 1905.4 \\
\hline \multirow{4}{*}{9} & Bean & 2.51 & 0.195 & 3.58 & 188.85 & 4.58 & 840.6 \\
\hline & Lettuce & 4.46 & 0.375 & 8.93 & 1271.5 & 6.075 & 2858.0 \\
\hline & Dill & 3.27 & 0.33 & 4.705 & 447 & 3.395 & 1529.9 \\
\hline & Clover & 11.94 & 0.165 & 3.945 & 280 & 2.755 & 1501.9 \\
\hline
\end{tabular}


Table 14. Mean concentration of trace elements in the edible parts of vegetables, cereals and clover which collected along Bhar El- Bakr drain during summer and winter 2017

\begin{tabular}{|c|c|c|c|c|c|c|c|}
\hline \multirow{2}{*}{ Site } & \multirow{2}{*}{ Plant name } & \multicolumn{6}{|c|}{ Trace elements (mg/kg D.M.) } \\
\hline & & $\mathbf{F e}$ & Mn & $\mathrm{Cu}$ & $\mathbf{Z n}$ & Co & Mo \\
\hline \multirow{5}{*}{2} & Lettuce & 304.7 & 62.85 & 31.36 & 68.5 & 0.64 & 0.105 \\
\hline & Wheat & 201.4 & 21.245 & 40.555 & 40.41 & 0.235 & 5.75 \\
\hline & Clover & 1293 & 43.975 & 26.625 & 38.825 & 0.93 & 3.795 \\
\hline & Hibiscus & 1184.5 & 67.9 & 31.74 & 55.45 & 0.7 & 0.62 \\
\hline & Onion & 211.45 & 15.53 & 29.2 & 40.1 & 0.07 & 0.45 \\
\hline \multirow{4}{*}{3} & Clover & 413.6 & 33.37 & 34.75 & 49.36 & 0.455 & 0.695 \\
\hline & Garlic & 212.35 & 13.93 & 24.935 & 40.4 & 0.125 & 0.525 \\
\hline & Cabbage & 591.5 & 31.46 & 27.27 & 42.18 & 0.37 & 1.315 \\
\hline & Wheat & 285.9 & 42.63 & 21.815 & 32.535 & 0.205 & 0.2 \\
\hline \multirow{8}{*}{4} & Cabbage & 327.6 & 21.945 & 29.88 & 23.16 & 0.405 & 3.69 \\
\hline & Clover & 714.5 & 35.195 & 29.075 & 31.655 & 0.43 & 1.605 \\
\hline & Bean & 183.05 & 23.14 & 30.55 & 39.95 & 0.285 & 5.715 \\
\hline & Lettuce & 1962 & 335.95 & 38.86 & 91.35 & 1.235 & 0.795 \\
\hline & Dill & 500.5 & 133.4 & 37.775 & 59.3 & 0.315 & 1.855 \\
\hline & Onion & 169.75 & 37.485 & 25.915 & 33.3 & 0.095 & 0.355 \\
\hline & Garlic & 107.95 & 11.52 & 21.825 & 24.6 & 0.055 & 0.35 \\
\hline & Wheat & 214.1 & 34.31 & 25.645 & 39.57 & 0.075 & 0.62 \\
\hline \multirow{10}{*}{6} & Clover & 398.3 & 28.105 & 33.085 & 54.7 & 0.545 & 7.13 \\
\hline & Lettuce & 575.5 & 49.09 & 28.01 & 85.85 & 0.395 & 0.4 \\
\hline & Hibiscus & 558 & 28.495 & 28.705 & 105.25 & 0.365 & 1.14 \\
\hline & Red pepper & 321.5 & 10.94 & 39.62 & 53.5 & 0.305 & -0.095 \\
\hline & Garlic & 116.5 & 5.925 & 18.43 & 17.595 & 0.185 & -0.08 \\
\hline & Bean & 201.4 & 21.245 & 40.555 & 40.41 & 0.235 & 5.75 \\
\hline & Wheat & 218.3 & 20.235 & 20.18 & 28.115 & 0.185 & 0.61 \\
\hline & Onion & 146.3 & 8.395 & 25.48 & 18.245 & 0.045 & 0.445 \\
\hline & Tomato & 310.8 & 19.985 & 28.415 & 30.9 & 0.235 & 0.485 \\
\hline & Dill & 519.5 & 28.115 & 27.705 & 53.1 & 0.27 & 0.9 \\
\hline \multirow{4}{*}{7} & eggplant & 196.2 & 9.115 & 20.43 & 25.72 & 0.1 & 0.19 \\
\hline & Parsley & 655 & 53.1 & 28.815 & 61.5 & 0.385 & 5.305 \\
\hline & Cucumber & 334.65 & 38.295 & 47.64 & 74.45 & 0.21 & 2.29 \\
\hline & Red Pepper & 143.15 & 11.795 & 23.37 & 25.7 & 0.115 & 0.735 \\
\hline \multirow{4}{*}{9} & Bean & 290.6 & 18.24 & 56.35 & 56.3 & 0.31 & 14.645 \\
\hline & Lettuce & 1284 & 55.75 & 34.51 & 87.35 & 0.94 & 0.195 \\
\hline & Dill & 470.65 & 23.855 & 21.53 & 70.2 & 0.3 & 1.365 \\
\hline & Clover & 359.5 & 13.945 & 25.275 & 48.99 & 0.27 & 4.93 \\
\hline
\end{tabular}

In this study cadmium was detected more than permissible limits of plant samples, and $\mathrm{Cd}$ detected more than the permissible FAO/WHO (2001) safe limit $0.2 \mathrm{mg} / \mathrm{kg}$ in $62 \%$ from all plant samples. Thus, the $\mathrm{Cd}$ level in edible parts of the studied seems unsafe usage; it must be make regular monitoring and prevent to use these as foodstuff.

The contents of $\mathrm{Zn}$ in all samples under studied were lower than the permissible levels $99.4 \mathrm{mg} / \mathrm{kg}$ by FAO/WHO, (2001).

The content of $\mathrm{Cu}$ in this study was found within the safe limits $73.00 \mathrm{mg} / \mathrm{kg}$ (FAO/WHO, 2001).
Chromium $(\mathrm{Cr})$ in all studied samples were exceeded the (FAO/WHO, 2001) $(0.05 \mathrm{mg} / \mathrm{kg})$ and FAO/WHO, (1993) by $0.1 \mathrm{mg} / \mathrm{kg}$.

The levels of Manganese were exceeded the safe limit reported by Arif et al., 2011 (20 mg/kg) in major studied plant samples except some as: tubers of garlic, leaves of onions (site $2 \& 6$ ), fruits of eggplants, red pepper and shoot parts of clover plants in site 7 . Bartlett, (1999) described Mn as a key of life because of its importance in photosynthesis, the vital link in a large number of processes occurring in human and animal organisms. 
Nickel concentration in the vegetables of this study area was found in the average of $1.99 \mathrm{mg} / \mathrm{kg}$ in fruits of tomato plants (site 6) to $14.065 \mathrm{mg} / \mathrm{kg}$ in leaves of cabbage (site 4) as a clear from Table (13), which is higher than that $0.1 \mathrm{mg} / \mathrm{kg}$ as given by $\mathrm{FAO} / \mathrm{WHO}$, (2002).

Results from this study showed the concentration values of cobalt was within the normal range of 0.01$1.00 \mathrm{mg} / \mathrm{kg}$ reported by (Khan et al., 2008) except leaves of lettuce in site 4 by $1.235 \mathrm{mg} / \mathrm{kg}$ dry weight.

The values of Mo in this study were under the toxicity level ( $<20 \mathrm{mg} / \mathrm{kg}$ dry weight) Kostova, et al., (2008).

In this concern, Badawy, et al., (2013) carried out a field survey of Bahr El-Bakr drain and El-Salam canal for metal contamination in water, soils and plants in locations irrigated. The concentration of heavy metals in the edible parts foreggplant, rice, beet, okra, maize, palm, guava, pepper which grown in both sites showed significant increases of heavy metal contents in plants grown in Bahr El-Bakr site, as compared with those grown in El-Salam site. The $\mathrm{Al}, \mathrm{B}, \mathrm{Co}, \mathrm{Cr}, \mathrm{Cu}, \mathrm{Fe}, \mathrm{Mn}$, $\mathrm{Mo}, \mathrm{Ni}, \mathrm{Sr}$ and $\mathrm{Zn}$ concentrations were above the safe limits of WHO/ FAO,(1993) standards in all the agricultural foodstuff. Both adults and children consuming these vegetables grown in wastewater irrigated soil ingest significant amounts of these metals and thus can cause serious health problems.

The main source of heavy metals and trace elements contamination of the edible parts of plants was mainly from the contaminated water which presence as unsoluble form (showed by digested method). In this context, Lasat, (2002) stated that, there are several lines of evidence suggested that soil microorganisms possess mechanisms capable of altering environmental mobility of metal contaminants with subsequent effects on the potential for root uptake. Production of organic acids by soil bacteria, including rhizobacteria (Goldstein et al., 1999) may promote solubilization, mobility and bioavailability of metals by lowering the $\mathrm{pH}$ and supplying metal complexing organic acid ligands. (Barker, et al., 1998)

This mobilization of metal can be achieved by: First, metal chelation molecules (phytosiderophores) can be secreted into the rhizosphere to chelate and solubilize metal, e.g., mugineic acid, avenic acid and nicotianamine (Kinnersely, 1993). Metal-chelating proteins, perhaps related to metallothioneins or $\delta$ glutamyl cysteinyl-isopeptides ( $\delta$ EC-isopeptides) (Rauser, 1990). Second, plant roots can solubilize heavy metals by acidifying their environment with protons extruded from the roots. A lower $\mathrm{pH}$ solubilizers metal precipitates and releases soil-bound ions into the soil. (Crowley, et al., 1991).

\section{CONCLUSION}

It can be suggested some point swhich contributed in the limitation and reduction of polluted drains present in Egypt as follows: (1) Activating the law and punishing violators who use contaminated water to irrigate food or fodder crops. (2) Construction of covered drainage networks. (3) Adequate treatment of waste water by simple technologies using a low cost and environmental friendly treatment of sewage water especially for the small communities. (4) Forbidden the mixing of industrial waste with sewage in order to limit the problems in waste water treatment. (5) Regulation and minimizing the use of fertilizers and pesticides during the cultivation of food and fodder plants.

\section{REFERENCES}

Abdallah, S.A., A.A. Elmanama, M.I. Fahd and S. Afifi. 2005. Microbiological beach sand quality in the gaza strip in comparison to sea water. Polish J. Environ. Stud. 14(6): 841-850.

Abdel-Azeem, A. M., T. S. Abdel-Mneim, M. E. Ibrahim, M. A. Hassan, and M. Y. Saleh. 2007. Effects of long-term heavy metals contamination on diversity of terricolous fungi and nematodes in Egypt- a case study. Water Air Soil Pollut. 186:233-254.

Abdel-Shafy, H. and R. O. Aly.2002. Water issue in Egypt: Resources, pollution and protection endeavors. CEJOEM. 8(1):3-21.

Abdel-Wahaab, R. and M. I. Badawy. 2004. Water quality assessment of the River Nile system: An overview. Biomedical \& Environ. Sci. 17:87- 100.

Agency for Toxic Substances and Disease Registry (ATSDR). 2008. Draft toxicological profile for cadmium Atlanta: US Department of Health and Human Services, Agency for toxic substances and disease registry. Available from: http://www.atsdr.cdc.gov/toxprofiles/tp5-p.pdf

Alloway, B.J. 1995. Heavy Metals in Soils. Blackie Academic and Professional, Chapman and Hall, London. 368 p.

Aly, H.S. and A.A.Abou Elsoad.2009. Effect of Environmental pollution on leaf composition, fruit set and fruit quality of Hayany date palm. Alex.Sci.Exch.J.30: 3036.

Arif, I. A., H. A. Khan, A. A. Al-Homaidan and A. Ahamed. 2011.Determination of $\mathrm{Cu}, \mathrm{Mn}, \mathrm{Hg}, \mathrm{Pb}$ and $\mathrm{Zn}$ in the outer tissue washings, outer tissues and inner tissues of different vegetables using ICP-OES. J. Environ. Stud. 20: 834 841.

Ashraf, M.A., M. Ahmad, S. Aqib, K.S. Balkhair and N.K.A. Bakar 2014. Chemical species of metallic elements in the aquatic environment of an ex-mining catchment. Water Environ. Res. 86: 77-728. 
ASTM, (American Society for Testing and Materials).2002. Annual book of ASTM standards. Baltimore, MD, USA, Vol. 11.01, 939 pp.

Badawy, R. K. M. A. Amr and H.E. Osman .2013. Health risk assessment of heavy metals and microbial activity in soils and agricultural food staff from wastewater irrigation at Sahl El-Hessania area, Egypt. J. of Appl. Sci. Res. 9(4): 3091-3107.

Baker, A.S. and R. Smith. 1969. "Extracting solution for potentiometric determination of nitrate in plant tissue". J. Agric. Food Chem. 17:1284-1287.

Barker, W. W., S. A.Welch, S.Chu and J. F. Banfield. 1998. "Experimental observations of the effects of bacteria on aluminosilicate weathering". Amer. Mineral. 83: 15511563.

Bartlett, R. J. 1999."Characterizing soil redox behavior". In: SoilPhysical Chemistry, $2^{\text {nd }}$ Edition, D. L. Sparks (ed.). CRC Press, Boca Raton, FL. pp. 371-397.

Bhuyan, M. S., M. Abu Bakar, A.Akhtar, M. B. Hossain, M. M.Ali and Md. Sh.Islam. 2017. Heavy metal contamination in surface water and sediment of the Meghna River, Bangladesh. Environ. Nanotech. Monitoring Manage. 8: 273-279.

Bodur, M. N. and M.Ergin. 1994. Geochemical characteristics of the recent sediment from the Sea of Marmara. Chem. Geol. 115:73-101

Canadian soil quality guidelines (CSQG). 2007. The protection of environmental and human health, Summary tables. Updated September. In: Canadian environmental quality guidelines. 1999. Canadian Council of Ministers of the Environment, Winnipeg.

Chakravarty, M. and A. D.Patgiri. 2009. Metal pollution assessment in sediments of the Dikrong River, NE India. J. Hum. Ecol. 27 (1): 63-67.

Chan, T.Y. 2011. Vegetable-borne nitrate and nitrite and the risk of methaemoglobinaemia. Toxicology Letters. 200: 107-108.

Correia, M., A.M. Barroso, F. Barroso, D. Soares, M.P. Oliveira and C. Delerue-Matos. 2010. Contribution of different vegetable types to exogenous nitrate and nitrite exposure. Food Chemistry. 120: 960-966.

Cottenie, A., M. Verloo, L. Kiekens, G.Velgh and R.Camcrlynck. 1982. Chemical Analysis of Plant and Soil. Anal. Agrochem., State Univ.,Ghent,Belgium.

Crabill, C., R. Donald, J. Snelling, R. Foust, G. Southam. 1999. Impact of sediment fecal coliform reservoirs on seasonal water quality in Oak Creek, Arizona. Water Res. 33(9): 2163.

Crowley, D.E., Y.C. Wang, C.P.P. Reid and P.J. Szaaniszlo. 1991. Mechanisms of iron acquisition from siderophores by microorganisms and plants. Plant Soil. 130:179-198.

E. 2010. Effect of treated wastewater irrigation on antibiotic resistance in agricultural soil bacteria. Environ. Health Problem. _ _ Lhttp://www.ehf.org.il/en/grant/effect-treated Wastewater-irrigation-antibiotic-resistance-agriculturalı isoil-bacteria-dr-eddiè
Edberg, S.C., E.W. Rice, R.J. Karlin, M.J. Allen. 2000. Escherichia coli the best biological drinking water indicator for public health protection. J. Appl. Microbiol. 88:106-116.

EL-Bady, M. S. M. 2016. New approach for calculation of pollution indices of the soils by heavy metals: case study for soils of Bahr El-Baqar Region, South of Manzala Lagoon, Egypt. Inter. J. Chem. Tech. Res. 9(4): 461-474.

El-Shenawy, M.A. 2005. Staphylococcus aureus studies on microorganisms isolated from faba bean and fecal indicators in Egyptian coastal waters of Aqaba Gulf and Red Sea. M.Sc. Thesis, Fac. Sci. Zigzag Univ.

European Union. 2002. Heavy Metals in Wastes, European Commission - _ _ on - onvironment.

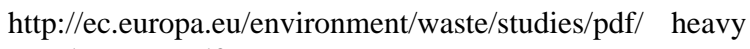
metals report.pdf

Food and Agriculture Organization/World Health Organization (FAO/WHO). 1993. Food Additives and Contaminants. Joints FAO/WHO Food Standard Programme ALINORM. 01/12A 1-289.

Food and Agriculture Organization/World Health Organization (FAO/WHO). 2001. Codex Alimentarius Commission: Food Additives and Contaminants. Joint FAO/WHO Food Standards programme, ALINORM. 01/12A:1-289.

Food and Agriculture Organization/World Health Organization (FAO/WHO). 2002. Human vitamin and mineral requirements: report of a joint $\mathrm{FAO} / \mathrm{WHO}$ expert consultation Bangkok, Thailand. Rome: Food and Agriculture Organization; Geneva: World Health Organization. p. 223-9.

Gangolli, S. D., P. A. Van den Brandt, V. J. Feron, C. Janzowsky, J. H. Koeman, G. J. A. Speijers, B.Spiegelhalder, R. Walker and J. S. Wishnok . 1994. Assessment of nitrate, nitrite and N-nitroso compounds. Europ. J. Pharmacology: Environ. Toxic. Pharmacology Section. 292: 1-38.

Gerba, C.P. 2000 Assessment of enteric pathogen shedding by bathers during recreational activity and its impact on water quality. Quantitative Microbiology. 2: 55-68.

Geesey, G.G. and J.W. Costerton. 1979. Microbiology of a northern river: bacterial distribution and relationship to suspended sediment and organic carbon. Can. J. Microbiol. 25(9):1058-62.

Goldstein, A. H., K. Bravermann and N.Osorio. 1999. Evidence for mutualism between a plant growing in a phosphate-limited desert environment and a mineral phosphate solubilizing (MPS) rhizobacterium. FEMS Microbiol. Ecol. 30: 295-300.

Haller, L., J. Pote, J.L. Loizeau, W. Wildi. 2009. Distribution and survival of faecal indicator bacteria in the sediments of the Bay of Vidy, Lake Geneva, Switzerland. Ecol. Indic. 9:540-547

Hesse, P.R. 1971. A Textbook in Soil Chemical Analysis. London: William Glowe. 
Hord, N.G., Y.Tang and N.S. Bryan. 2009. Food sources of nitrates and nitrites: the physiologic context for potential health benefits. Am. J. Clin. Nutr. 90: 1-10.

Huang, K., S. Lin. 2003. Consequences and implication of heavy metal spatial in sediments of Keelung River drainage basin, Taiwan. Chemosphere J. 53:1113-1121

Islam, E. U., X. Yang, H.E. L. Zhen and Q. Mahmood. 2007. Assessing potential dietary toxicity of heavy metals in selected vegetalbles and food crops. J. Zheijiang Univ. Sci. B. 8s: (1):1-13.

Kaymak, H. C. 2013. Effect of Nitrogen Forms On Growth, Yield And Nitrate Accumulation Of Cultivated Purslane (Portulaca Oleracea L.). Bulgarian. J. Agric. Sci. 19 (No 3):444-449.

Khan, S., L.Aijun, S. Zhang, Q. Hu and Y. G. Zhu. 2008. Accumulation of polycyclic aromatic hydrocarbon and heavy metals in lettuce grown in the soils contaminated with long-term wastewater irrigation. J. Hazardous Materials. 152(2): 506 - 515.

Kinnersely, A. M. 1993. The role of phytochelates in plants in plant growth and productivity. Plant Growth Regulation, 12: $207-217$.

Kostova, D., V. Kanazirska and M. Kamburova. 2008. A comparative analysis of different vegetable crops for content of manganese and molybdenum. Agron. Res. 6(2): 477-488.

Lasat, M. M. 2002. Phytoextraction of toxic metals: A review of biological mechanisms. J. Environ. Qual. 31: 109-120.

Lee, C.M., T.Y.Lin, C.C.Lin, G.A.Kohbodi, A.Bhatt, R.Lee and J.A. Jay. 2006. Persistence of fecal indicator bacteria in Santa Monica Bay beach sediments. Water Res 40:2593-2602.

Li, Y., Y.Wang, X.Gou, Y.Su and G.Wang. 2006. Risk assessment of heavy metals in soils and vegetables around non-ferrous metals mining and smelting sites, Baiyin, China. J. of Environ. Sci. 18(6):1124-1134.

Lopez, A., A. Pollice, G. Laera, A. Lonigro, P. Rubino and R. Passino. 2007. Reuse of membrane filtered municipal wastewater for irrigating vegetable crops. Proc. of the International Conference on Water Saving in Mediterranean Agriculture \& Future Research Needs, Valenzano (Bari) 14/17 febbraio . Vol. 2: 181-189.

Ma, Q. Y., S. J. Traina and T. J. Logan. 1994. Effect of aqueous $\mathrm{Al}, \mathrm{Cd}, \mathrm{Fe}(\mathrm{II}), \mathrm{Ni}$ and $\mathrm{Zn}$ on $\mathrm{Pb}$ immobilization by hydroxyapatite. Environ. Sci. Technol. 28(7):1219-1228.

Malakuti, M. and A. bybourdi. 2004. Optimum consumption for Fertilizer: An effective step in increasing performance, improving quality, decreasing pollutants in vegetables and improving community status. Applied Agriculture Science. pp. $244-245$.

Mandi, L. and M. Abissy. 2000. Utilization of Arundo donax and Typha latifolia for heavy metals removal from urban sewage water and reuse of treated sewage water for alfalfa irrigation. In: Third International Symposium on Sewage Water, Reclamation, Recycling and Reuse, Paris, France. pp. 158-165.
Marshall, R. (Ed.).1992, Standard Methods For the Examination of Dairy Products, 16th ed., APHA, Washington, D.C.

McGrath, S.P. 1995. Nickel. In: Heavy metals in Soils. Alloway, B. J. (Ed). Blackie Academic \& Professional, London..

Muller, G. 1969 "Index of Geoaccumulation in sediments of the Rhine River".Geo. J. 2:108-118.

Munir, M. and A. Mohammad. 2004."Forage yield and nutrient uptake as influenced by secondary treated sewage water". J. Plant Nutr.27:351-365

MWRI, Article (60) for water quality in Nile Branches. 2009 The regulation for ministerial Decree No. 402 issued in 2009، by virtue of Egyptian Law 48/1982.

Nile Basin National Water. 2005. Quality Monitoring Baseline Study Report for Egypt. 127.

Norvell, W.A. 1984. Comparison of chelating agents as extractants for metals in diverse soil materials. Soil Sci. Soc. Am. J. 48:1285 -1292.

Nowrouz, P., H. Taghipour, S. Dastgiri, Y. Bafandeh, K. Hashemimajd. 2012. Nitrate Determination of Vegetables in Varzeghan City, North-western Iran. Health Promotion Perspectives. 2: 244-250.

Ondo, J.A., R.Menye Biyogo, F.Eba, P.Prudent, D.Fotio, M.Ollui - Mboulou and J. Omva-Zue. 2013. Accumulation of soil - borne aluminium, iron, manganese and zinc in plants cultivated in the region of Moanda (Gabon) and nutritional characteristics of the edible parts harvested. J. Sci. Food Agri. 93(10): 2549-2555.

Ostafiychuk, B.K., I.M. Budzulyak, N.Y.A. Ivanichok, B.I.R achiy and R.P. Lisovsky. 2014. The effect of thermal modification on the development of carbon material microporous structure. J. 1 of Vas.Stef. Proc. Nat. Univ.1 (1): 41-53.

Palese, A.M., V. Pasquale, G. Celano, G. Figliuolo, S. Masi, C. Xiloyannis. 2009. Irrigation of olive groves in Southern Italy with treated municipal wastewater: Effects on microbiological quality of soil and fruits. Agric. Ecosyst. Environ. 129:43-51.

Peach, K. and M. V. Tracey. 1956. Modern Methods of plant analysis. I. Springer-Verlag Berlin.

G.A. Peyvast. 2006. Vegetables Farming. Danesh Pazir Press. P. 487.

Qui, X.X., D.F. Huang, S.X. Cai, F. Chen, Z.G. Ren, Y.C. Cai. 2000. Investigation on Vegetables pollution and pollution sources and its control in Fuzhou, Fujian Province. Fujian J. Agric. Sci. 15:16-21.

Rauser, W. E. 1990. Phytochelatins. Annu. Rev Biochem. 59: $61-86$.

Ravet, K., J. ouraine, J. oucherez, F.Briat, F. Gaymant and F.Cellier. 2009. erritins control interaction between iron homeostasis and oxidative stress in Arabidopsis. Plant. 7(3): 400-412. 
Rowe, D.R. and I. M. Abdel-Magid. 1995. Handbook of wastewater reclamation and reuse. CRC Press, Inc. 550.

Sanders, B.F., F. Arega, M. Sutula. 2005. Modeling of the dry weather tidal cycling of faecal indicator bacteria in surface waters of an intertidal wetland. Water Res. 39: 3394-408

Santamaria, P. 2006. Nitrate in vegetables: toxicity, content, intake and EC regulation:. J. Sci. Food Agri. 86: 10-17.

Scancar, J., V. Stibilj and R. Milacic. 2004. Determination of aluminum in Slovenian foodstuffs and its leachability from aluminum-cookware. Food Chem. 85:151-157.

Seshan, B.R.R., U.Natesan and K.Deepthi. 2010. Geochemical and statistical approach for evaluation of heavy metal pollution in core sediments in southeast coast of India. Int. J. Environ. Sci. Tech. 7 (2): 291-306.

Shehu,K., I.A. Salau, A.B. Kasarawa and A. I. Umar. 2014. Study on fungi associated with metropolitan waste water used for irrigation on soil in sokoto metropolis. Global Advanced Res. J. of Agric. Science (ISSN: 2315-5094) Vol. 3(6): 148-151.

Singh, D. and S.K. Chauhan. 2011. Organic acids of crop plants in aluminum detoxification Curr. Sci. 100:15091515.

Škrbić, B. and N.Miljević. 2002. An Evaluation of Residues at an Oil Refinery Site Following Fires. J. Environ. Sci. and Health. 37(6):1029-1039.

Sparks, D.L. 1998. Soil Physical Chemistry. $2^{\text {nd }}$ Edition, Lewis Publishers, CRC Press, London. WHO. 2011. Guidelines for Drinking Water Quality. (4th ed.).

Tae-Rang,K., C.Bu-Chul, J.Sung-Ae, K.Eun-Hee. 2011. Evaluation of nitrate contents of organic and conventional farming vegetables in Korea. International Conference on Chemical, Biological and Environmental Sciences. (ICCEBS).
Taylor, S.R., S.M. Mclennan. 1995. The geochemical evolution of the continental crust. Rev. Geophys. 33: 241265

Turekian, K. K. and K. H.Wedepohl. 1961. Distribution of the elements in some major units of the earth's crust. Geo. Soc. Am. Bull. 72 (2):175-192.

Walker, R. 1990. Nitrates, nitrites and N-nitroso-compounds: a review of the occurrence in food and diet and the toxicological implications. Food Addit. Contamin. 7(3):717-768.

Wedepohl, K.H. 1995. The composition of the continental crust. Geochimicaet Cosmochimica Acta 59: 1-217,1-239. doi: 10.1016/0016-7037(95)00038-2.

World Health Organization (WHO). 1989. Health Guidelines for the Use of Wastewater in Agriculture and Aquaculture, Report of WHO Scientific Group, WHO Technical Report Series No. 778, World Health Organization, Geneva. 74.

World Health Organization (WHO). 1993. Guidelines for drinking water quality (2nded.,vol. 1).Recommendations. Geneva: World Health Organization.

World Health Organization (WHO). 2001. Water Quality: Guidelines, Standards and Health. Edited by Lorna Fewtrell and Jamie Bartram. Published by IWA Publishing, London, UK.

World Health Organization (WHO). 2006. A compendium of drinking-water quality standards in the eastern Mediterranean region. World Health Organization Regional Office for the Eastern Mediterranean Regional Centre for Environmental Health Activities CEHA.

Yehia, H.M. and S.Z. Sabae. 2011. Microbial pollution of water in ElSalam canal, Egypt. Am Eurasian J. Agric. Environ. Sci. 11 (2):305-309. 


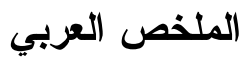

تقييم التلوث البيئي وتأثيره على نوعيه مصادر المياه و الأراضي والمحاصيل بالمنطقة المتاخمة لمصرف

\section{بحر البقر - شرق الالتا-مصر}

عبد الحميد مصطفى الاعصر ، شيرين شحاتة مريد ، أمل محد عمر سالم، رهام كامل إبر اهيم

خطورة هي Cd \& Pb ميث أن قيم متوسط معامل النلوث

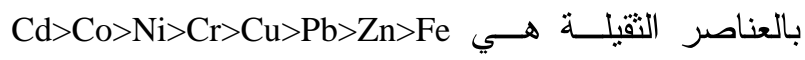
بالترتيب مما يشير إلى أن عينات التربة كانت غنية بعنصر

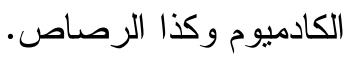

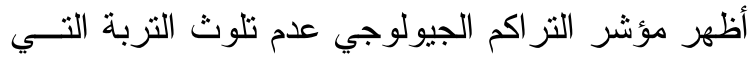
Fe, Zn, Ni, Co \& Cr تروى من مصرف بحر البقر بعناصير مع تلوث منوسط بعنصر الرصاص وتلوث عالي بعنـــر بلهر

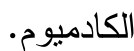

وجد ارتفاع ملحوظ في محتـوى النتـرات بــالأجزاء المستخدمة للأكل من نباتات الخضر الورقية ـ يتدرج تركيز

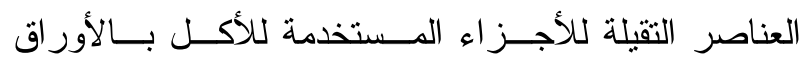

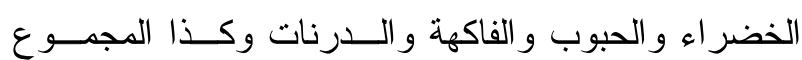

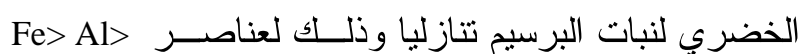
$\mathrm{Zn}<\mathrm{Cu}>\mathrm{Mn}>\mathrm{B}>\mathrm{Ni}>\mathrm{Cr}>\mathrm{Pb}>\mathrm{Ba}>\mathrm{V}>\mathrm{Mo}>\mathrm{Co}<\mathrm{Cd}$.

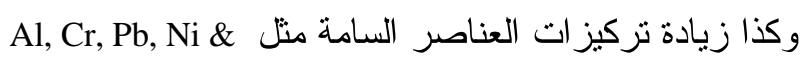
Cd.

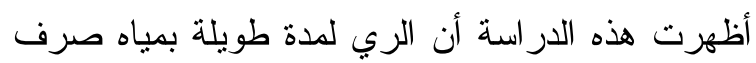

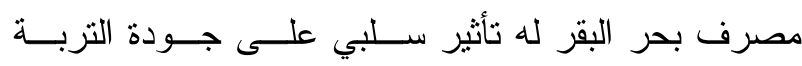
و النباتات كيميائيا وميكروبيولوجيا بهذه المنطقة.
تم تقدير الأثر البيئي للمياه الملوثة على طــول مـسار مصرف بحر البقر . حيث تم جمع عينات مختلفـــة ممنالـــة لللياه و التربة و الأجز اء القابلة للأكل للخضروات و الحبوب التبات

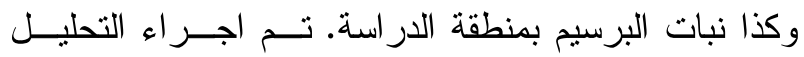

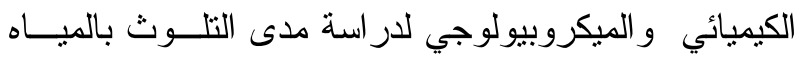
و النزبة والنبات. أظهر الفحص الكيميائي لعينــات الميــاه

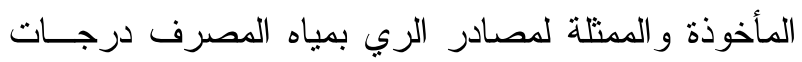

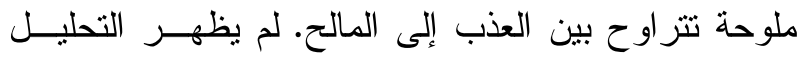

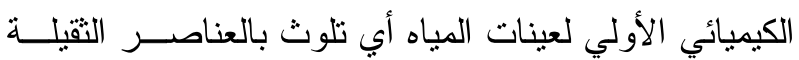

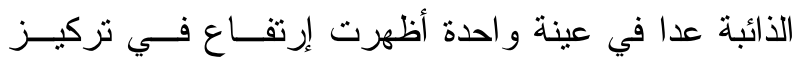

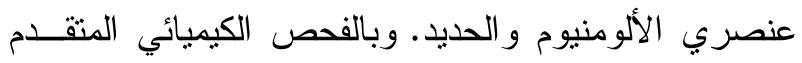

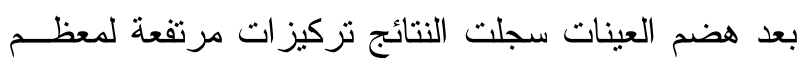

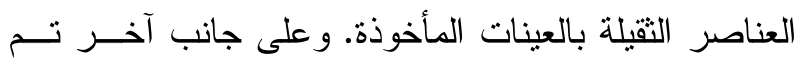

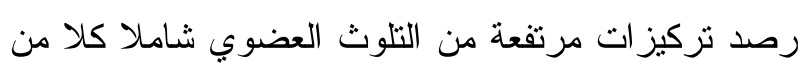
TOD , COD بمعظم عينات المياه.

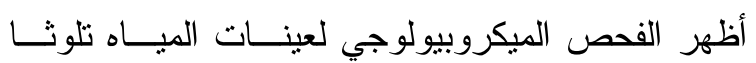

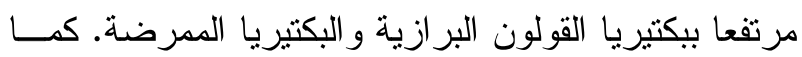
أظهر تلوث ميكروبيولوجي عالي لعينات التربة مقارنة بمياه

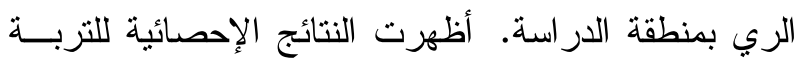

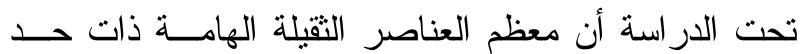

